\title{
Updating and loss of color terminology in Yurakaré: An interdisciplinary point of view ${ }^{\text {th }}$
}

\author{
Rik van Gijn ${ }^{\mathrm{a}, *}$, Vincent Hirtzel ${ }^{\mathrm{b}, 1}$, Sonja Gipper ${ }^{\mathrm{a}, 2}$ \\ ${ }^{a}$ MPI for Psycholinguistics, PO Box 310, NL-6500 AH Nijmegen, The Netherlands \\ b Laboratoire d'Anthropologie Sociale, 52 rue du Cardinal Lemoine, 75005 Paris, France
}

\section{A R T I C L E I N F O}

Keywords:

Yurakaré

Color terms

Language contact

Updating

\begin{abstract}
A B S T R A C T
In spite of the well-established idea that language contact is fundamental for explaining language change, this aspect has been remarkably absent in most studies of color term evolution. This paper discusses the changes in the color system of Yurakaré (unclassified, Bolivia) that have occurred during the last 200 years, as a result of intensive contact with Spanish language and culture. Developing the new theoretical concept of 'updating', we will show that different contexts have resulted in qualitatively different changes to the color system of the language.
\end{abstract}

(c) 2010 Elsevier Ltd. All rights reserved.

\section{Introduction}

This paper studies the processes of change that have taken place in the color nomenclature and classification of Yurakaré during the last 200 years under the influence of language contact. Yurakaré, an unclassified ${ }^{3}$ language spoken by some 2500 people in the tropical lowlands of central Bolivia, has been exposed to Spanish in a permanent and increasing way since the beginning of the 18th century, and is now one of the many languages in danger of disappearing.

The objective of this paper is twofold. First, it is a descriptive study of the evolution of a color-designating system of an underdescribed language, focusing on language contact, and discerning different forms and types of change that have taken place in the last 200 years. Second, at a more general level, we propose a model of language change termed 'updating'. 4 Through this notion, we argue that the different changes that have affected the lexical level of nomenclature (the terms used for color designation) as well as the classification of the colors proper (the way in which color terms subsume more or less specific color areas) are the result of a series of adjustments made by the speakers to their own system, adapting it to their historical experiences with their Spanish-speaking neighbors.

To achieve our objectives, we compare three data points. The first is one of the oldest written source on the language, published by Adam in 1893. This work contains a grammatical description and word list compiled on the basis of field notes of Franciscan missionary Lacueva, who collected data on the language in a period between the 1790s and the 1820s. The

\footnotetext{
4f The three authors are working together on the DoBeS documentation project "The documentation of Yurakaré" (www.mpi.nl/dobes/projects/yurakare).

* Corresponding author at: Radboud University Nijmegen, Dept. of Linguistics, PO Box 9103, 6500 HD, Nijmegen, The Netherlands. Tel.: +31 (0)24 3521176.

E-mail addresses: rik.vangijn@mpi.nl (R.van Gijn), hirtzel@hotmail.com (V. Hirtzel), sonja.gipper@mpi.nl (S. Gipper).

1 Tel.: +33(0)144271731.

${ }^{2}$ Tel.: +31 (0)24 3521176 .

${ }^{3}$ Some hypotheses have been put forward with respect to the genetic affiliation of Yurakaré (cf. Swadesh, 1962; Suárez, 1974; Greenberg, 1987). Neither of these proposals, however, is convincing, and Yurakaré is best considered unclassified, or an isolate language.

${ }^{4}$ The notion of updating was first proposed by one of the authors (Hirtzel, 2007), under the French term actualisation, applying to diachronic transformations of mythological narratives.
} 
information in this historical source is compared to two further data points: the results of a color naming test conducted by the authors in two different Yurakaré villages. These villages differ significantly in the degree of exposure they have had to the Spanish-speaking world. This three-way comparison allows us to infer the different phases and types of change that have occurred in the indigenous color system in the last 200 years.

We will start with a discussion of the theoretical framework used in this paper in Section 2, followed by a positioning of this paper vis-à-vis color theory in Section 3. Section 4 describes the experimental set-up. In the next Sections 5 and 6, we present and analyze the data, before coming to a conclusion in Section 7.

\section{Language updating}

\subsection{Defining language updating}

We define language updating as the linguistic processing within a given conceptual domain of a change in experiences of the speakers that are relevant to that domain. By domain we mean any kind of conception or realm of experience that is evoked by a word or an expression thereby constituting the basis for its meaning (Langacker, 2008, p. 44). Langacker makes a distinction between basic and non-basic domains. Non-basic domains correspond to complex conceptions that can incorporate other domains "or are in some sense reducible to more fundamental notions" (Langacker, 2008, p. 44). Basic domains, on the other hand, cannot be reduced to more fundamental notions. They include time, space, and "the ranges of unanalyzed experience associated with the various senses: color space (the range of colors we are capable of experiencing) pitch (the range of pitches we can perceive), temperature, taste and smell, and so on" (Langacker, 2008, p. 44).

Language updating is the result of an adjustment of any conceptual domain. As a linguistic process it also depends on the way concepts are profiled with respect to the relevant domain. In the case of a basic domain such as color space, updating will depend on the dimensions (or variables) that structure color space: hue, brightness, saturation, as well as other, less frequent ones. ${ }^{5}$ It is important to note that color space (at least in terms of the three traditional variables) is continuous, which has the inherent consequence that words profiling a region in this space have fuzzy and flexible boundaries, and are built up around a certain prototype (cf. Rosch, 1973). This means that within a continuous domain, a language gives labels to different areas, ${ }^{6}$ but these labels can also apply (but less felicitously) to adjacent zones if there is no competing label of which the exemplar is a better (more prototypical) manifestation. This in turn means that there will be weaker areas (i.e. areas that are not close to a focal point), and areas of competition between two terms.

Language updating in general refers to any kind of change in the lexical-conceptual organization of a domain as a result of new experiences of the speakers. This change can take on many forms, which can broadly be calibrated with respect to two dimensions: additive versus subtractive changes, and system-preserving versus system-restructuring changes. ${ }^{7}$ The first dimension refers to the 'orientation' of language updating: towards addition or towards subtraction. Both orientations can be explained by the same functional motivation, aligning language with the experiences of the speakers. Additive updating is the linguistic processing of new experiences, subtractive updating (loss) is the linguistic processing of a loss of experiences, such that a domain or a concept within a domain is no longer backed by current reality causing it to fall into disuse. The second dimension refers to how disruptive a particular change is to the organizational principles of the domain. We distinguish two broad situation types: system-preserving vs. system-restructuring (cf. Aikhenvald (2007, p. 20) for a similar distinction). The nature of the distinction can be illustrated with respect to color terminology. An example of a system-preserving change to the color domain of a language is the addition of a term designating an area in color space that was only covered in the periphery of other color terms. The core meaning of the original color terms is left relatively intact. A more disruptive instance of language updating would be the addition of a color term that designates an area that is part of the core of an existing term, which in turn shifts in meaning. We will come back to this dimension in the next Subsection, as well as in the course of this paper.

The perspective of updating builds on the idea of language adaptation, coined in Coulmas (1989) and defined as a "kind of language change, [that] has both natural ${ }^{8}$ and intentional aspects" (Coulmas, 1989, p. 2) and as "a theory of how languages adjust when they come under pressure resulting from new or changed functional requirements" (Coulmas, 1989). Like Coulmas, we also want to stress the role of intentionality in the process of language updating: language updating is not something that 'happens' to speakers. As a result of a new experience, a speaker can decide to use a new form or give a new meaning to an existing form, and his/her interlocutors will accept or reject this use which eventually may spread to the wider community and in this way become standard language practice. However, the point we want to stress here is that without the intentional level, the process of updating would not occur. The importance of the historical-agentive role of the speakers in general in the

\footnotetext{
${ }^{5}$ In fact, Yurakaré presents such a case where the dimension of incandescence plays a role, see Section 5.

${ }^{6}$ Depending on the organization, the central area of a concept can be smaller or bigger for a label, e.g. the language that distinguishes only light from dark colors is likely to have larger central areas for its labels than the language that makes much more distinctions within the same domain.

7 A third dimension may be reframing: (metaphorical or metonymical) extension of a term, i.e. profiling a term with respect to another domain, but as we are concerned with the changes within a particular domain here, we ignore this dimension for the purposes of this paper.

${ }^{8}$ Coulmas does not specify what he exactly means when he speaks of 'natural aspects', but it presumably relates to the following quote: "language adaptation is, for the most part, a gradual and continuous process that takes place almost unnoticed by the speech community" (1989, p. 21). We do not deny the existence of unintentional language change (e.g. phonological or phonetic change, the gradual loss of case systems, or the reorganization of alignment systems), but the notion of language updating does not have anything to say about these changes, which are presumably governed by independent principles such as economy and/or iconicity.
} 
development of their own language is self-evident. Nevertheless, that does not mean that the individual creativity of each speaker is completely unrestricted. It is for instance constrained by the (implicit) language norms of the speaker community and, in a wider sense by the local language ideology, as is stressed by various authors (Silverstein, 1979; Woolard and Schieffelin, 1994). In this last sense it can be said that the updating process is always related to the reflexive process in which speakers as members of a speech community are engaged in (re)defining their identity through their linguistic practices, a situation particularly important for example in cases of multilingualism or the colonial encounter.

The term 'updating' is intended as a morally neutral term. It is far removed from perspectives that presuppose the existence of a 'pure' language, and in which language change is regarded as a process of decay or contamination of the language in question. The term updating also differs from the position on the other end of the moral spectrum, in which language change is regarded in Darwinist-evolutionary terms in the sense that changing languages are somehow intrinsically defective, and push towards an equally intrinsic 'fitter' standard in order to survive. When speakers introduce a color word into their language that covers an area in color space previously not or poorly classified, we can say that the previous version of the language was perceived by the speakers as falling short in encoding the speaker's experiences linguistically in a satisfactory way. But this does not mean that the previous version of the language in question was intrinsically defective; all languages simply adapt to new circumstances, innovations take place all the time. Nobody's perfect, not even languages.

\subsection{Language updating in the context of language contact}

A factor that makes the study of language updating (or any approach to language change) more complex, is the fact that speaker communities are generally not completely monolingual, since they are usually in contact with other speaker communities. The notion of language updating quite naturally extends to this circumstance: contact with other people in general, and with other linguistic, social or ethnic groups inevitably leads to new experiences, which may find their way into the languages involved. In this sense, contact-induced change is a specific form of language updating. What makes it specific is the context in which language updating takes place because of (a) the availability of an exogenous source from which speakers can draw linguistic material, and (b) the sociological pressure for change often associated with contact situations, especially in the case of political or cultural dominance of one of the groups involved.

In their paradigm-setting book, Thomason and Kaufman (1988) focus on the role of socio-historical processes in explaining patterns of contact-induced language change and distinguish three broad socio-historical frames, ${ }^{9}$ emphasizing the role of the degree of bilingualism as the vehicle of change (1988, p. 50) that leads to different linguistic outcomes:

1. Casual contact, little bilingualism

>> only non-basic vocabulary borrowed

2. Intensive contact, widespread bilingualism over long period of time

>> much lexical borrowing, moderate to heavy structural borrowing

3. Overwhelming long-term cultural pressure from source language group

>> massive grammatical replacement or language death

One of the most important generalizations that can be made on the basis of these scenarios is that the more intensive and long-term the contact and the more widespread (and arguably higher degree of) bilingualism, the more abstract the linguistic material that is borrowed. ${ }^{10}$

The main focus in Thomason and Kaufman's work is on the societal level. As a result of this macro-perspective, bilingualism is conceptualized as a function of the intensity of contact, and only quantitatively differentiated in its socio-historical frame. However, to fully understand how language updating is possible through bilingualism it is necessary to go beyond that characterization. In this respect the work of Van Coetsem $(1988,1995,2000)$ is relevant.

Van Coetsem focuses on the role of the individual, bilingual speaker in the transfer of linguistic material from one language to another. He positions his work as follows: "we have to be aware of the distinction between the speech transfer proper and the possible diffusion of the result of that transfer throughout the speaker community and beyond. What we are interested in here is not the diffusion, but the transfer phenomenon" (1995, p. 65). In this sense Van Coetsem's work is complementary to that of Thomason and Kaufman, who focus on diffusion in terms of sociolinguistic and socio-historical processes.

Van Coetsem distinguishes three parameters: transfer, language dominance, and agency. Transfer simply refers to the transmission of linguistic material or patterns from a source language (SL) to a recipient language (RL). Language dominance refers to "the greater proficiency that a speaker has in one language (L1) as compared to another language (L2)" (Van Coetsem, 1995, p. 70). Language dominance is connected to agency, which concerns the question of who is performing

\footnotetext{
9 These socio-historical frames only apply to their notion of borrowing, defined as "the incorporation of foreign features into a group's native language by speakers of that language" (Thomason and Kaufman, 1988, p. 37). The authors contrast borrowing with interference through shift, which refers to traces of the original language of the speaker group that has shifted to another language. Language updating only corresponds to Thomason and Kaufman's notion of borrowing, not to interference through shift, therefore we ignore the latter notion in our representation of Thomason and Kaufman's work.

10 This generalization should be regarded as a tendency. There are other factors involved that may give rise to counterexamples, like a strong local language ideology directed towards cultural conservatism. For a case of a resistant, or 'conservative' group that wants to preserve the "purity" of their language in a bilingual situation see the case of the Tewa, studied by Kroskrity (1998), or for the tendency towards 'syncretism' in the same context see Hill and Hill's (1986) study of Mexicano.
} 
the transfer. When an RL-dominant speaker is the agent of the transfer, s/he borrows linguistic material from SL into RL. If an SL-dominant speaker is the agent of the transfer, s/he imposes features of his/her dominant language upon the RL. Borrowing typically involves lexical material, and is a much more conscious process than imposition. Imposition is characteristic of L2 acquisition, and has a much more coercive character than borrowing; it furthermore typically involves more structural features than borrowing.

Van Coetsem's framework introduces a number of important additions to the work of Thomason and Kaufman. One is that the notion of language dominance allows for differentiations in the degree of dominance, whereas Thomason and Kaufman speak about native language, which is not gradable. Moreover, what is or is not the native language of a speaker is a fixed fact; language dominance can change over time, and according to the situation (e.g. depending on the topic of conversation). Another advantage of Van Coetsem's model is that it allows for a differentiation between the politically dominant language and the linguistically dominant language.

A full-fledged theory of contact-induced language change requires elaborate psycholinguistic and sociolinguistic components in line with the work of Thomason and Kaufman and Van Coetsem, but it should also incorporate ideas on the role of linguistic-conceptual structure. Thomason and Kaufman claim that "it is the sociolinguistic history of the speakers, and not the structure of their language, that is the primary determinant of the linguistic outcome of language contact" (Thomason and Kaufman, 1988, p. 34). Perhaps due to this strong position in Thomason and Kaufman's influential work, much of the focus of attention in the recent literature on contact-induced change has been on socio-historical factors. There have certainly been proposals that take into account the role of language structure (e.g. Myers-Scotton, 1993; Van Coetsem, 1988, 1995 ) but these approaches focus on the penetrability of (sub)systems of the recipient language, and they hinge on the lexical vs. grammatical distinction. Language updating approaches the role of language structure in contact-induced change by taking into account the conceptual organization of domains, not only of the recipient language, but also of the source language, focusing on the interplay between them. In this way, we hope to offer a more sophisticated answer to the question how language structure can influence the outcomes of language contact.

\section{The relation to color theory}

We emphasize that this paper is intended as a contribution to the study of contact-induced change, and as such it approaches color theory from a widely neglected point of view. ${ }^{11}$ As a result of the perspective we take on color theory, we do not need to assume a position with respect to many of the dominant topics in color-theoretic discussions.

Arguably the most hotly debated issue in the literature on color across languages is whether color-term systems have a universal or language-specific character and path of development. Some studies point to relativity effects (e.g. Lenneberg and Roberts, 1956), others to universal tendencies (e.g. Berlin and Kay, 1969). Whether or not the evolution of color-term systems follows a universal path is in fact irrelevant to this paper. The empirical results obtained in this study are used for an analysis in terms of contact-induced change, concerning all types of color terms, not only the basic ones. This does not mean that we will disregard the internal classification or even stratification of the color term lexicon in Yurakaré where we think it is relevant for the topic of this paper, but this kind of internal classification is not intended to uncover the 'core' color terms of Yurakaré, on the basis of which universalist claims are usually tested.

A further point of considerable debate concerns the question whether differences between languages in the linguistic coding of color categories have consequences for color cognition (coding, remembering, recognition). On the one hand it has been argued that color foci are universally more salient perceptually (Rosch Heider, 1972) and consequently that the linguistic codification of colors does not influence color cognition. However, this perspective has been challenged by others (Roberson et al., 2000, 2005) who suggest that language does determine certain cognitive processes for specific color categories, and that the foci (best examples) of these categories are a derived phenomenon. This question is beside the point of this paper. Our focus is on the mechanisms of contact-induced language change, not on the relation between language and thought.

A final point to which we wish to answer is the use of fixed stimulus arrays as an inadequate means to elicit color terminology, without paying attention to the actual uses of the color terms, their grammatical status, and their semantic range (cf. e.g. Lucy, 1997). We share this criticism when the objective is to describe a system of color terminology, and therefore we have supplemented the results of the test with information on grammar, semantics and usage where we could. We are also aware that a definition of color space in terms of hue, brightness and saturation does not exhaustively describe all possible color nomenclature. ${ }^{12}$ Nevertheless, the main objective of this paper is not an exhaustive description of the color-term system of Yurakaré, but rather a study of its processes of change. As we do not have ample historical data, our methodology is to reason back in time on the basis of a contemporary comparison between two villages. To make sure that we compare like with like, the

\footnotetext{
11 In the color literature, there are of course many references to the diffusion of certain color terms which suppose contact-induced change, but few analyze this phenomenon in the corresponding linguistic perspective. It has also been proposed that the cause of uniformization of the basic color terms across languages may be caused by European colonial expansion. (cf. Tornay, 1978, p. xxxi; Saunders and van Brakel, 1997, p. 169).

12 Other parameters sometimes must be invoked, as the aforementioned incandescence (cf. also Section 5). Another example is Classical Latin, which distinguishes between non-brilliant/brilliant forms of black (ater/niger), white (albus/candidus), and possibly also red (rubeo/rutilus), cf. Ott, 1899. For the description of these distinctions a parameter of 'brilliance' is required.
} 
use of identical stimulus material in both villages is indispensable for making any kind of generalization. Our primary interest is not so much the answers themselves, but rather the differences and similiarities between the answers of the consultants.

\section{Experimental setup and methodology}

The results presented in this paper are primarily based on empirical data, elicited with the help of stimuli, presented in the form of a booklet containing 80 color chips, developed at the Max Planck Institute for Psycholinguistics in Nijmegen (cf. Majid and Levinson, 2007). Speakers were presented with a color chip, and asked to give the term they use for that color.

The data were collected in two Yurakaré villages with a different historical and socio-cultural profile. The first community is Tres de Mayo, situated halfway the Sécure River in the TIPNIS (Indigenous Territory and National Park Isiboro-Sécure); the other is La Misión, situated along the Chapare River in the TCO (Indigenous Communal Territories) Yuracaré (see Fig. 1). La

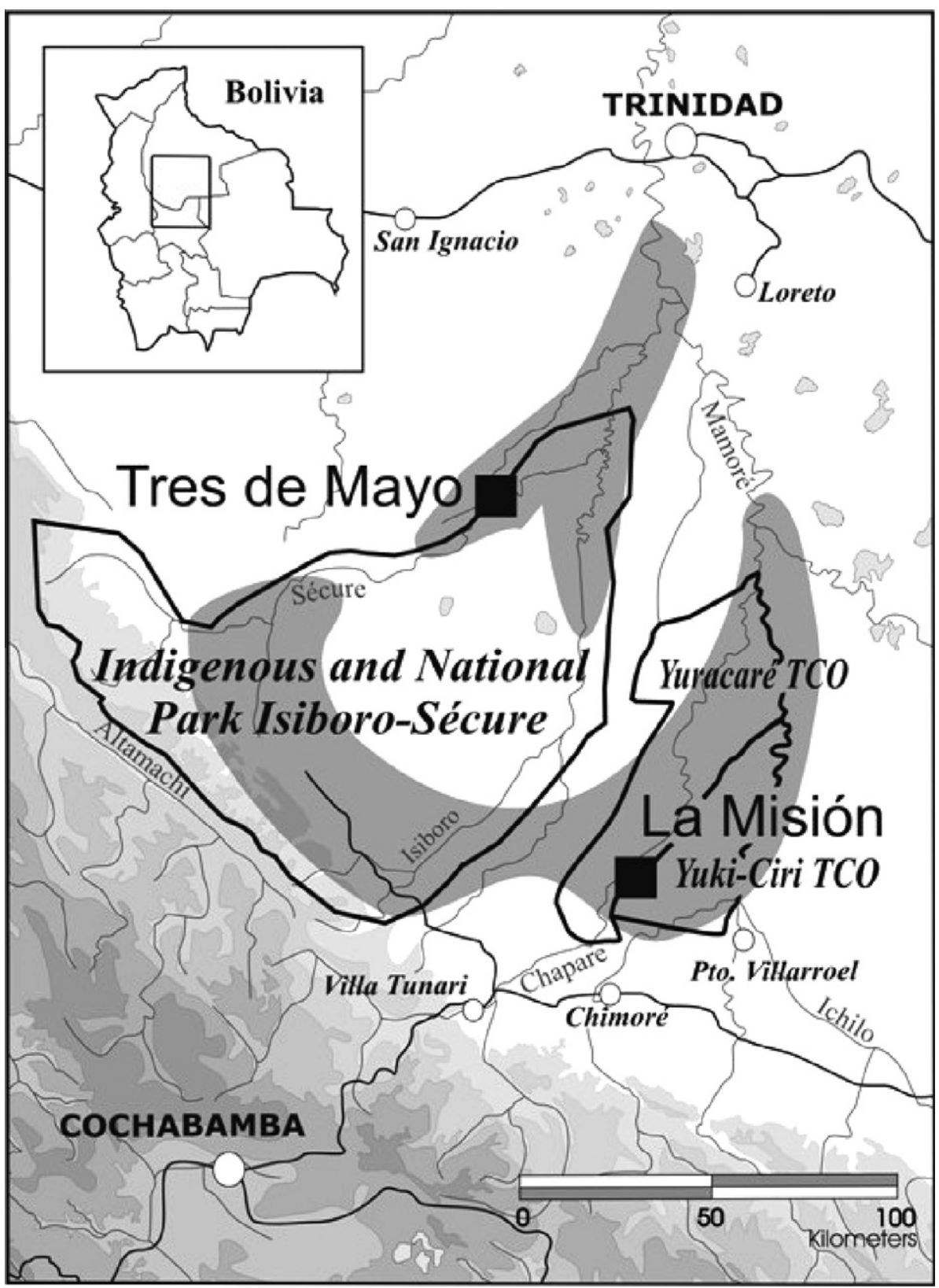

Fig. 1. Map of Yurakaré territory with fieldwork locations. 
Misión is situated in an area where exposure to Spanish started earlier and was much more intense than in the area of Tres de Mayo. As a result, language updating in La Misión is one generational step further advanced than in Tres de Mayo.

This comparative experimental set-up has allowed us to track differences in the color systems of these villages that are due to the difference in the degree of exposure to Spanish. Based on these differences, we can determine certain traits of updating, which will be discussed in Section 6. On the other hand, the points in common between the villages enable us, in combination with a study of historical documents, to reconstruct the principal traits of the indigenous system, and to infer the way the updates have taken place between the end of the 18 th and now.

In Tres de Mayo, 14 consultants, aged between 17 and 64 (mean = 33.4; 8 male, 6 female), participated in the color naming experiment. Nine consultants did the complete test, five consultants only a part of it. We have minimally nine answers, maximally 14 answers per color (mean $=11.7$ ). Demographically, Tres de Mayo has a rather large group of 20-40 year-olds, and not many elder people. Younger people (under 15) generally do not have an active knowledge of the language. Therefore the age group between 20 and 40 is overrepresented in the Tres de Mayo sample. As everyday practice of the language in Tres de Mayo is common in this group of speakers, most people were able to do the test without difficulties, and could answer without much delay to the test stimuli.

In La Misión, 10 persons participated in the test. The consultants were aged between 24 and 68 (mean = 47.1) and half of them belong to the generation of pëpëw "grandfathers". This is a result of the fact that everyday use of the language is less common in age groups under 50 than in Tres de Mayo. Because the speakers belonging to the younger $(<50)$ generation generally felt insecure about their competence in the indigenous color vocabulary, many of them declined to do the test. Furthermore, the sample is predominantly masculine (7 out of 10). This is due to the fact that many women, even if they were fluent speakers of Yurakaré, also declined to do the test, because of a more general reluctance to speak Yurakaré to outsiders. ${ }^{13}$ We gathered between 10 and 14 answers per stimulus (mean $=10.8$ ). As a result of the process of language loss, reaction times were generally much longer than in Tres de Mayo, but we do not investigate this point statistically in this paper. ${ }^{14}$

There was a methodological difference between Tres de Mayo and La Misión in that in the former community, people were simply asked what the name of that color was. In La Mision, in order to avoid answers completely in terms of the Spanish color-classification system, it was stressed that they should mention the Yurakaré term.

Before starting the discussion of the collected material we will give a brief description of the parameters that define color space, in order to facilitate the understanding of the results to readers not familiar with color coding. The stimulus booklet contains colors which are defined according to the influential Munsell color coding system, based on hue, brightness, and saturation. Munsell considers ten hues ${ }^{15}$ :

(1) $R-Y R-Y-G Y-G-B G-B-P B-P-R P-R$

These hues form a circular scale, i.e. the next hue after RP is R, followed by YR and so on. The different points on this scale represented by the initials of the English color terms are not discretely separated from each other, but gradually pass over into each other. Munsell has developed a measure for different points between one hue and another, going from 1 to 10 , with 5 as the central value:

(2) $\mathrm{R} \quad \mathrm{YR} \quad \mathrm{Y}$

...56789101234567891012345....

The next parameter is brightness. This scale pertains to the relative lightness of the color, and runs from black (darkest) to white (lightest). Different points on this scale are also given numbers, from 1 (black) to 10 (white). The final parameter is called saturation (called chroma in the Munsell terminology), relating to the relative purity of a color. This scale can be said to run from grey to a pure color, and is also expressed by a number, going from 1 (grey) to a maximum, which ranges from 6 to 16, depending on the hue. The colors in the sample are represented at their maximum possible saturation level.

These parameters translate into a code for each color. As an example, consider the following code:

(3) $5 \mathrm{R} 6 / 12$

This code indicates that the color is situated in the central area (5) of the hue 'red' (R), with medium-light brightness (6), and with a high saturation value (12).

The booklet developed at the MPI Nijmegen contains a subset of the possible Munsell colors (330) of 80 colors covering all hues, at equally spaced points on the continuum: for a given hue area, the points 5 and 10 were chosen. As to brightness, for

\footnotetext{
${ }^{13}$ This type of behaviour seems typical for a majority of women in this area of La Misión, and is suggestive of a higher sensitivity of these women to differences in status between Yurakaré and Spanish.

${ }^{14}$ We are aware that parameters like age and gender may play a role in the structure of the results, but the number of participants and their skewed distribution over these parameters do not allow us to reach any viable conclusions on these topics.

${ }^{15} \mathrm{R}=$ red, $\mathrm{P}=$ purple, $\mathrm{B}=$ blue, $\mathrm{G}=$ green, $\mathrm{Y}=$ yellow.
} 
Table 1

Comparison of current and historical data.

\begin{tabular}{|c|c|c|c|c|}
\hline Modern transcription $^{a}$ & Approximate translation & Transcription Lacueva & Translation Lacueva: Spanish (English) & Ref. $^{b}$ \\
\hline bubushi & yellow & bubusi & amarillo (yellow) & 57 \\
\hline beymi & orange & vehimi & achiote (urucú, name of plant) & 53 \\
\hline tëbêttëbë & red & teveteve & colorado (red) & 69 \\
\hline kulákkula & pink & culacula & colorado claro (light red) & 69 \\
\hline itértere, & purple & itere & morado (purple) & 97 \\
\hline yёnnêjyënnë & dark blue & yegneyegne & azul (blue) & 68 \\
\hline shítiri & turquoise & sitiri & añil (indigo plant) & 58 \\
\hline \multirow[t]{2}{*}{ sëjsëshi } & green, blue & sesesi & verde (green) & 119 \\
\hline & & xexesi & azul (blue) & 62 \\
\hline boloshi & white & bololosi & blanco (white) & 63 \\
\hline \multirow[t]{2}{*}{ wuriwurishi } & black & ureuresi & negra cosa (black thing) & 99 \\
\hline & & & morado (purple) & 97 \\
\hline \multirow[t]{2}{*}{ shüjshüshi } & blackish & sasasi $^{c}$ & negra cosa (black thing) & 99 \\
\hline & & & moreno (brown) & 97 \\
\hline shëshëshë & dark & - & & \\
\hline püjtüshi & pale & - & & \\
\hline bajábaja & dim, dull & - & & \\
\hline bombombo & rarefied, low density light & bombombo & turbio (turbid) & 117 \\
\hline sololto & glowing red & sololto & colorado (red) & 119 \\
\hline
\end{tabular}

a The transcription of Yurakaré items used in this paper follows the resolution of the meeting on the orthography of Yurakaré, held in Santa Cruz de la Sierra, 25th-26th July, 2007. The transcription of consonants is identical to Spanish, with the exception of [sh] which corresponds to / $\int /$. The vowels are also identical to Spanish, except for [ë], which corresponds to /æ/, and [ü] to /ö/. When stress falls on another syllable than the penultimate, it is marked with the superscript ['], otherwise it is unmarked. When non-penultimate stress falls on [ë] or [ü], it is indicated with [^]. For a description of Yurakaré phonology as well as a description of the grammar cf. Van Gijn (2006).

b The references correspond to the page numbers of the dictionary by Lacueva (Adam, 1893).

c There is some insecurity with respect to the interpretation of the form sasasi as a transcription of shüjshüshi. Close inspection of Lacueva's transcriptions of other words containing the same sounds suggests that it is the most probable interpretation, but it cannot be totally excluded that sasasi is a transcription of shëshëshë.

each hue area, four levels of brightness were chosen: 2, 4, 6, and 8 . So for instance for the hue $5 \mathrm{Y}$, there are four examples, at brightness level 2, 4, 6, and 8. For $10 \mathrm{Y}$ as well, and so on.

\section{The indigenous system of color classification}

To establish the list of indigenous color terms, we base our analysis on two interrelated and complementary parameters. First of all, we rely on a linguistic form parameter: color terms in Yurakaré are generally derived from nouns in morphologically productive and similar ways. Secondly, we use a statistical parameter: we consider those terms as indigenous color terms that are mentioned frequently in both villages, by several consultants, and that cannot be interpreted as loan words. ${ }^{16}$ To test the resulting list we compared it to the historical data of Lacueva (Adam, 1893). Both our and Lacueva's list are rendered in Table 1.

All color terms listed by Lacueva are still used in present-day Yurakaré. The terms shëshëshë, püjtüshi, bajábaja are not mentioned by Lacueva. This is probably not because they were not used at that time, but because they are difficult to translate into Spanish color terms, as they are not hue-grounded. The only potential color term mentioned by Lacueva we will not consider in the remainder of this paper is sololto, which was never used spontaneously by consultants in the color test. Haenke, in a short vocabulary compiled in 1796, translates it as "red" (Gicklhorn, 1997 [1962-1963], p. 134), as does Lacueva. It is cited by Ribera, Rivero and Rocha, who worked with Yurakare speakers from the low Isiboro-Sécure in the North, with the meaning "pink" (1991). We registered sololto with the meaning 'estar con braza' (have smoldering wood), derived from the noun solso 'smoldering wood'. The use of this word as a color term is connected to the glowing observed in the smoldering wood, i.e. an incandescent color, and not just a reflected one. This is corroborated by the translation 'pink of being warm (metal, smoldering wood)' proposed by New Tribes Mission dictionary (1991, p. 97). Sololto cannot be interpreted on the basis of the three Munsell parameters alone. It needs the additional dimension of incandescence. This parameter is not represented in the Munsell stimuli, which explains why sololto was never mentioned in the test. ${ }^{17}$

The words for color in Yurakaré, which are adjectives, are partly transparently derived from nouns in two ways: either by means of the similative marker -shi 'be like', or by means of reduplication, forming a descriptive adjective that highlights a

\footnotetext{
16 Though it is true that some Yurakaré color words go beyond mere color designation (see below), they cannot apply to other perceptual domains. In this sense, the color terms form a coherent cognitive-linguistic domain. This does not mean that we consider this a universal characteristic of color terms.

17 The term can be used to refer to the color of red lights. There are also some lexicalized uses of the term which are not, properly speaking, incandescent colors, but these uses still retain an element of glowing intensity, as if the referent was emitting light. Examples are the Andean cock-of-the-rock (Rupicola peruvianus) for the radiant red plumage of the male, and an unidentified dermatological disorder that brings out ardent red stains.
} 
salient physical feature of an object. In the case of color terms, this feature is the color of the source object. In a few cases the word that refers to the source object can also, without any modifications, refer to a color. Some color terms have more than one possibility to be derived from a noun, e.g. in the case of itere (same word as source object) itere-shi (with the similative marker) and iter tere (reduplication) which all refer to the same color. ${ }^{18}$

Color words can also be modified in the several ways. Hedging is indicated by means of the markers -mashi 'somewhat', -nñu 'diminutive, a little' as well as (marginally) by nish 'negator' in some cases (e.g. nish tëbêttëbë 'not red' is actually used to indicate that the color chip is not a good example of tëbêttëbë, but nevertheless red is its closest label); the use of the adverb chalmalë 'defective' is restricted to La Misión in our data. Augmentation or intensification is achieved by means of partial reduplication, which is prefixed to the root and followed by the inserted element $j$ : sëj sëjsëshi, buj bubushi, etc.), or by means of the adverb eméjemesh 'very, highly, genuinely'. Color names can also modify other colors, by means of the adverbializing suffix -sh (or deletion of the final $i$ for color terms ending in -shi), e.g. in sëjsë-sh bubushi 'greenish yellow', tëbêttëbësh bubushi 'reddish yellow'.

We will not go into the matter of linguistic structure of the color terms in detail in the remainder of this paper, but it is important to briefly outline some of our assumptions with respect to linguistic structure, because we have based some decisions in classifying the color terms mentioned on them.

(1) We have counted different derivations on the basis of one and the same noun as one type (most importantly in the case of itere and its variants, but also in e.g. beymi vs. beymi-shi, yënnë vs. yënëj yënë).

(2) We have disregarded elements that modify the color terms, and looked at the principal color term mentioned in the answer to the stimuli only, i.e. elements like -mashi, -nñu, etc., but also for instance nish and modifying color terms.

(3) If people gave two different answers for one and the same chip, we have counted them as two valid entries.

We will now discuss the indigenous color terms, their approximate designation and their relation to objects insofar as we have information on these issues. The first group of color names refers to colors that can be related to hues (sometimes in combination with brightness), the second group cannot be easily related to hue, but is rather related to brightness and saturation.

\subsection{Hue-related color terms}

As has been mentioned above, our main source of information for the color system of Yurakaré are the results of the color naming test introduced in Section 4. Apart from this test, we have carried out an additional test for some of the colors, which can be termed the Focal Color Test, where we asked a number of consultants to look through the booklet and indicate the best instances of a particular color term. After this, they were asked to pick the best example of this color term out of the selection they had made.

Bubushi designates colors within the Yellow and Yellow/Red area, especially with a high value of brightness. There is some spill-over into light red. The word bubushi also means 'ripe'. With this sense bubushi has specialized to designate the ripe banana, in opposition to the state where it is still green. This lexicalized use, however, is not the exclusive interpretation of bubushi with the meaning 'ripe'; it can in principle be applied to all kinds of ripe fruit. ${ }^{19}$ The noun bubbu from which the term is derived, designates the pollen of a flower or the yolk of an egg (Adam, 1893, p. 87). Present-day Yurakare preserves these meanings, but the latter translation is also given for bubushi in New Tribes Mission (1991, p. 19). Furthermore, bubbu refers to yellowish genital secretion of both men and women, and it is also used to indicate pus where it is synonym with another term, a-junti. Bubu-tëjmi ${ }^{20}$ is a compound containing the head tëjmi, another word meaning 'ripe' but which, in combination with $b u b u$, refers to an atmospheric manifestation of yellow clouds with a reputation of being hazardous to the health of children. The term appears in some cases in compound forms for some plants or animals, such as bubush-samu (Puma concolor), puma (lit. yellow-jaguar) and bubush-wishwi, which designates an unidentified snake, (lit. yellow-tail). The lexicalized expression bubush $i$-tanti 'have a yellow face/eyes' indicates that someone is in bad health whereas bubush-pulë lit. 'yellow testicle' is a joking and offending expression.

The term tëbêttëbë is the reduplicated form of the noun tëbbë 'blood'. It covers the Red and Red/Purple hues, especially with medium brightness. In contrast to bubushi, there are no metonymical or metaphorical uses of this word. It can be used to describe the color of many objects (e.g. feathers of a bird, fruits, but also the sunrays in the morning or evening). There are several tinctorial plants that can be used to produce a red color, but they have not been productive as color names for red except in the case of beymi (see below).

We classify the term kulákkula under the heading of hue-related color terms, but its connection to hue is somewhat problematic, given the fact that, especially in Tres de Mayo, answers covered many different hue areas and brightness values,

\footnotetext{
${ }^{18}$ In fact, the non-derived use of source terms and the multi-derivational potential are diagnostics for distinguishing different layers of color terms in Yurakaré. Well-established and probably older color terms, which tend to have a more opaque connection to the source indicated by the noun (if the source can be traced at all) have a fixed, derived form, whereas newer color terms, which tend to have a clear and transparent relation to the source object associated with the color term, can be referred to by the underived source nouns and often have more than one possible (and optional) derivation.

19 Nevertheless, some speakers do not accept the use of bubushi for non-yellow ripe fruit.

20 The geminate consonant is lost in compounds.
} 
both in the standard test and in the Focal Color Test. It seems that the color term is specializing towards light RP and P, but it is probable that originally, kulákkula was not connected exclusively to this specific hue area. The morphological form (reduplication) of the word kulákkula suggests that it is derived from the word kula 'to cook' or 'to be ready (cooked)'. Another lexicalized word related to kula is ajula (with a postvocalic lenition of $/ \mathrm{k} /$ provoked by the addition of the prefix $a$ - 'incompletive/progressive'), which means 'to ripen' in the sense that a fruit is just beginning to obtain its color, whatever its actual color is (ajula papayu 'The papaya is beginning to be orange/green'; ajula winnu 'The chilli pepper is beginning to be red'). Nevertheless, this color transition mostly refers to a process where the final color is situated in between the Y, R and RP ranges. ${ }^{21}$ Lacueva mentions it with the translation 'ripe', but also 'dawn, daybreak' (Adam, 1893, pp. 94, 57). Even though kulákkula can describe the color aspect of something, it can also be used to describe another type of situation. A common gloss for kulákkula in La Misión is to use the term to refer to the "color" of the body after a physical effort. New Tribes Mission (1991, p. 33) also mentions the translation 'to have a red face of physical effort' next to the more hue-related translation 'pink'. These connections suggest that kula, ajula, and kulákkula can be described as referring to the process of a change of color, which can be observed in several processes, like cooking of food, dawning, reddening of the face, and ripening. As the specialization of kulákkula is related to the process of updating, we will come back to this issue in the next Section.

The color term sëjsëshi is the term with the greatest hue extension, ranging from Blue via Blue/Green to Green and Green/ Yellow, in all brightness variants, except dark blue. Formally, the color-designating term seems to be derived from sëjsë which means 'fat, grease' (animal or vegetal) but this cannot be easily related to the color designated by sëjsëshi semantically. The designation of sëjsëshi where most consultants agreed is green, which seems to be its focus. Derivatives of sëjsëshi in the lexicon appear in toponymy, in the case of Sëjsësama 'green/blue water' a tributary of the upper Isiboro River, as well as in some botanical names, such as sëjsësh-winnu, a variety of chilipepper that keeps its green color throughout the ripening process, and sëjsësh-wijri, a variety of banana, most probably with the same characteristic.

Within the group of hue-related color terms, we distinguish a subgroup of color terms that are derived from the names of plants with tinctorial qualities. This subgroup consists of the following color terms.

The color name beymi (sometimes beyme) or beymishi, refers to the plant beymi (Bixa orellana; Eng. achiote). The color naming test as well as the Focal Color Test show that its main target hues are Yellow, Yellow/Red and Red, in all of these hue areas in the lighter variants. This is in accordance with its seeds which are coated with a red-orange/deep pink, wax-like substance. This pan-Amazonian tinctorial plant was used by the Yurakaré, mainly for corporal painting. To this end they used a 'make-up' called yarita, prepared with the dye of the seeds, mixed with the fat of the Spix's Guan ushawsha (a local bird). It serves also to paint the ornamental pattern of their beaten bark tuniques. Beymi competes with bubushi, but the former is highly marginal compared to the latter: where beymi was mentioned only 13 times ( 9 times in Tres de Mayo, 4 in La Misión), bubushi was mentioned 167 times (103 in Tres de Mayo, 64 in La Misión). As far as we know, there are no lexicalized compounds or derivations containing beymi.

The interchangeably used color terms itere(shi) and the reduplicated form itertere (variant itértere) are related to the word itere, which designates the plant Picramnia sellowii, ${ }^{22}$ the leaves of which are used to create a violet/purple dye. As color terms, these words are associated in particular with darker and middle-bright variants of Purple and Blue/Purple, as well as to the darkest variant of Red/Purple. The itere dye was especially used for painting traditional clothing made from tree bark, and for coloring cotton thread. ${ }^{23}$ Although there are no lexical derivations based on itere, it is possible that itere itself is a complex form based on the root -tere-, also found in the word teremtë 'draw, write', already mentioned by Lacueva with these meanings (Adam, 1893, pp. 81, 104). He also mentioned the reduplicative derived term teremteremte with the meaning 'painted' (Adam, 1893, p. 105).

Yënnë is the name of a tree (Genipa americana; Eng. genipap) that carries a fruit with the same name. On the inside, the unripe fruit has a fleshy whitish substance that can be applied directly onto a surface. When it dries up, the substance sticks to the surface and, as en effect of it oxidation, takes on a dark purple/blue color. The color term derived from this plant, yënnêjyënnë (variants yënêjyënë, yënëjnë) is associated with the Purple/Blue area, except for the lightest variants. There is overlap with itereshi/itertere, which has a wider color range, and which seems to be dominant over yënnêjyënnë in their areas of overlap. This plant was used for face painting in combination with beymi. After her menarche, and some days of seclusion, a girl was also painted entirely with yënnë. The reduplicated form yënnêjyënnë or yënëjnë, is commonly used to refer to hematomas. $^{24}$

The color term shitiri is the name of the indigo plant (Indigofera suffruticosa; Eng. indigo), ${ }^{25}$ which secretes a blue (indigo) dye after treatment with water. Colors associated with shítiri are Purple/Blue, and to a lesser extent Blue, Blue/Green, Green, and Green/Yellow. Because of its similar hue range, it is probable that shitiri functioned as a kind of sub-categorization of sëjsëshi. The plant is not common to the whole Yurakaré area, as it grows in the more mountainous areas of the Andean foot-

\footnotetext{
21 Possibly, there is another term, weyéjweye, with a similar meaning. It was actually used by one consultant of la Misión to designate a ripening fruit when it tends to a definitive color, which is black.

22 Identification by Thomas and Vandenbrook (2006, pp. 322-323).

23 The tinctorial use of this plant was common to the Preandine or montaña people of Bolivia. D'Orbigny mentioned the 'violet' color of the former Moseten cotton tunique (1844, p. 184). The Leko people used it as well (Weddell, 1853, p. 445).

${ }^{24}$ This sense meaning is perhaps more common in La Misión than its use as a color term. One young informant could translate hematoma, but did not know its color application.

25 Identification by Thomas and Vandenbrook (2006, pp. 210-212).
} 
Table 2

Distribution of color terms related to hue.

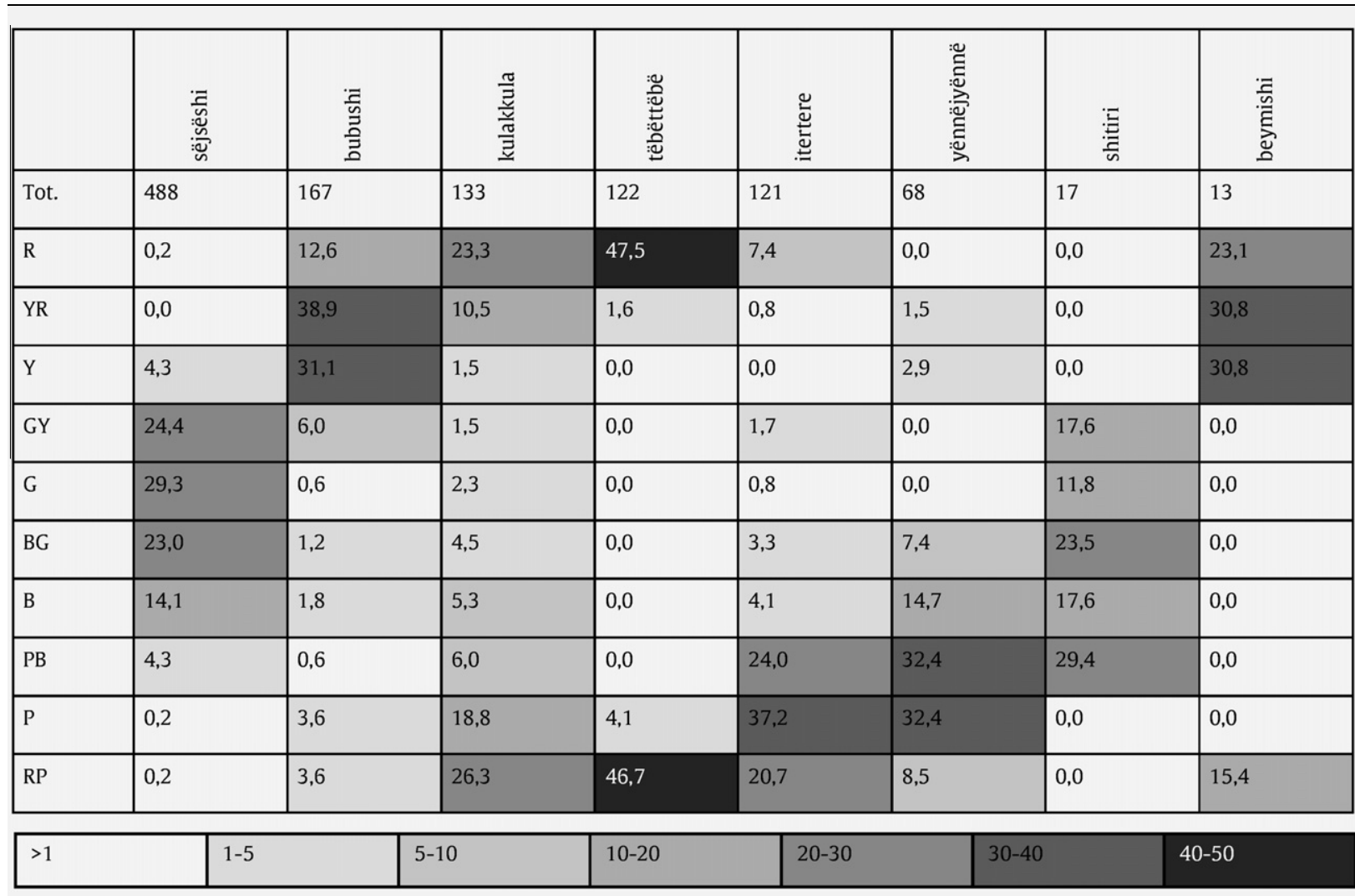

hills. Like beymi(shi), the word shítiri as a color term does not seem to be well installed, as it was mentioned only 17 times. It furthermore seems to be geographically limited, since it was never mentioned in La Misión. In this latter community where the plant was not known, shítiri could be used to refer to a kind of bluish nevus, or birthmarks, in a somewhat similar way as yënnêjyënnë is used for hematoma. The term appears in toponyms: Shitirisama is a secondary affluent of the Irupluma River which joins the upper Sécure River.

The color terms discussed so far can be divided over color space as shown in Table 2 .

The shades of grey indicate different percentages of the total of mentions for each color in relation to a particular hue area. For instance: the term sëjsëshi has $29.3 \%$ of all its mentions in the G hue area. The color terms are organized from left to right according to their frequency of mentions (see second row for absolute numbers), sëjsëshi being mentioned most often (488 times), then bubushi (167), etc.

As can be seen, the color terms related to plants (and dyes) are less frequent, with the exception of itertere. The opacity between sëjsëshi and its root suggests that the color term comes from a deep historical horizon. This is also true, though to a lesser extent, for bubushi.

\subsection{Non-hue-related color terms}

This group of color terms consists of terms referring to brightness, and terms referring to intensity.

The term boloshi (or bolloshi) refers to white. Even though this term has the morphology of a complex term based on a root bololo ${ }^{26}$ with the similative marker -shi, it does not have a transparent, literal meaning. Apart from the entry bololoshi, the root bololo does not appear anywhere else in the work of Lacueva (Adam, 1893). In our current research we have found several entries bollo (bolo) but none of them have a clear potential to be linked with the color term for white. There is for example a shrub called bolo with small white flowers, identified by Thomas and Vandenbrook (2006, pp. 354-355) as Pshychotria herzogii, but we do not know whether this plant is named after its white flowers or, vice versa, whether the plant

\footnotetext{
${ }^{26}$ Bololoshi is the term given by Lacueva (Adam, 1893, p. 63).
} 
Table 3

Distribution of Yurakaré color terms.

\begin{tabular}{|c|c|c|c|c|c|c|c|c|}
\hline & 2 & & 4 & & 6 & & 8 & \\
\hline $5 R$ & kape & 21 & tëbêttëbë & 91 & tëbêttëbë & 43 & kulákkula & 29 \\
\hline $10 \mathrm{R}$ & kape & 32 & tëbêttëbë & 65 & kulakforla & 33 & Koulakkula & 32 \\
\hline $5 Y R$ & Nate & 29 & kape & 36 & bubushi & 50 & bubushi & 46 \\
\hline $10 Y R$ & wuriwurishi & 39 & kape & 35 & bubushi & 82 & bubushi & 85 \\
\hline $5 Y$ & wuriwurishi & 48 & bajabajalkape & 29 & kape & 21 & bubushi & 87 \\
\hline $10 Y$ & wuriwurishi & 60 & sëjsëshi & 36 & sejseshi & 43 & bubushi & 87 \\
\hline $5 G Y$ & wuriwurishi & 25 & sëjsëshi & 68 & sëjsëshi & 74 & sëjsëshi & 48 \\
\hline $10 G Y$ & séseshi & 36 & sëjsëshi & 91 & sëjsëshi & 88 & sëjsëshi & 90 \\
\hline $5 G$ & sëjsëshi & 58 & sëjsëshi & 86 & sëjsëshi & 96 & sëjsëshi & 86 \\
\hline $10 \mathrm{G}$ & sëjsëshi & 50 & sëjsëshi & 100 & sëjsëshi & 83 & sëjsëshi & 87 \\
\hline $5 B G$ & sëjsëshi & 57 & sëjsëshi & 75 & sëjsëshi & 80 & sëjsëshi & 74 \\
\hline $10 \mathrm{BG}$ & sëjsëshi & 54 & sëjsëshi & 70 & sëjsëshi & 70 & sëjsëshi & 61 \\
\hline $5 \mathrm{~B}$ & sëjsëshi & 36 & sëjsëshi & 40 & sëjsëshi & 45 & sëjsëshi & 68 \\
\hline $10 \mathrm{~B}$ & wuriwurishi & 22 & sëjsëshi & 40 & sëjsëshi & 38 & boloshi & 29 \\
\hline $5 \mathrm{~PB}$ & sëjsëshi/yënêjyënë/asul & 21 & Séseshi & 32 & bajábaja & 30 & bajábaja & 24 \\
\hline $10 \mathrm{~PB}$ & itertere & 41 & itertere & 35 & yënêjyënë & 24 & boloshi & 82 \\
\hline $5 \mathrm{P}$ & itertere & 32 & itertere & 35 & itertere & 30 & boloshi & 54 \\
\hline $10 \mathrm{P}$ & itertere & 24 & itertere & 33 & Q Tulakkula & 25 & kulákkula & 36 \\
\hline $5 R P$ & itertere & 24 & tëbêttëbë & 57 & tébettebe & 36 & kulákkula & 22 \\
\hline 10RP & itertere & 38 & tëbêttëbë & 70 & tëbêttëbë & 63 & kulákkula & 50 \\
\hline
\end{tabular}

name gave rise to the color term. ${ }^{27}$ The booklet with sample colors did not have a pure example of white, but the name was sometimes assigned to very light versions of Blue, Purple/Blue and Purple, although consultants generally said that this was not really boloshi. The background color of the booklet, which is a pure white, was a better candidate. That boloshi appeared in particular with light Purple/Blue is due to the fact that this area is not very well covered by the indigenous color terms.

We are not aware of a cognate word for the reduplicated form wuriwurishi (variants uriwrishi, worewreshi) In the test, the color term refers was associated to very dark colors, especially in the hue areas of Yellow and Yellow/Red. Lacueva (Adam, 1893, pp. 97, 99) translates ureureshi with 'black thing' as well as with 'purple'. Consultants generally translate it with 'black', and in La Misión, consultants referred to the 'pure' black band of the booklet as a real example of wuriwurishi. For these reasons we consider wuriwurishi to refer to 'black'. The fact that it occurs in particular with dark yellow and dark yellow-red, is due to the fact that these hue areas have poor coverage by the indigenous terms.

The term shüjshüshi ( shüshüshi) also refers to black, and is in competition with wuriwurishi. Shüjshü means 'to drizzle', and it is generally associated with darkness, blackishness of the sky. The color term shüjshüshi is often translated in La Misión by Spanish "negruzco" (blackish), an appropriate translation considering examples such as the following: Ashansha shüjshüshi 'He has black teeth (e.g. of caries)'; Shüshüshi atantípëlë 'He has dark bags under his eyes'; Shüjshüshi bomboni ‘dark clouds,

\footnotetext{
27 Thomas and Vandenbrook (2006, pp. 33-34) also mention the Yurakaré name bolo for a herbaceous plant (Aciotis cauliata) but this seems to be a mistake. Additional research in one of the Yurakaré villages where Thomas and Vandenbrook conducted their fieldwork, suggests that Aciotis cauliata is named kankashi in Yurakaré.
} 
rain clouds'. There seems to be a regional aspect to the distribution of the color terms wuriwurishi and shüjshüshi: the former was mentioned 76 times in Tres de Mayo, and only 15 times in La Misión. Shüjshüshi shows an opposite pattern (10 times in Tres de Mayo, 24 times in La Misión).

The term shëshëshë also designates a dark color. It might be related to shëwë 'become night, dark', rather than to shëshë 'bifurcation', ${ }^{28}$ or shëjshë 'lipoma'. New Tribes Mission (1991, p. 100) translates it with 'the color coffee'. It is used in free speech mainly in the following three ways: (1) to characterize a dark-skinned person with the Spanish translation moreno 'brown' (where it competes with pëpëpë); (2) for dark types of feathers; (3) it is regularly associated with dark water. Shëshëshë does not have a clear correlation with a particular hue, although it surfaces relatively often in the darker areas of red and blue and adjacent hues. It might be that shëshëshë is in complementary distribution with wuriwurishi/shüjshüshi in 'filling up' the underrepresented color areas.

With the word püjtü some people refer to the lips and skin of a sick person, though not everyone accepts this form. No other cognate word of püjtü has been identified yet. The color term püjtüshi prototypically refers to the area of very light Blue and Purple, but it is often used as a modifier to indicate that a color is 'pale', e.g. in nish tëbêttëbë püjtüshimashi 'not really red, slightly pale' (10P8/6), or püjtüsh kulákkula 'pale kulákkula' (5R8/6). This meaning correlates with other possible translations of this term: in reference to a sick person it can be translated with 'pale', or 'anemic' (in La Misión) and has a rather negative connotation. In conclusion, püjtüshi seems to refer to very light colors, with a high level of white in them. It can in principle be used for all hues, but it surfaces mainly in the area of light purple and blue, which is poorly covered by hue-grounded indigenous color terms. In Table 3 (see below) the 10B8 to 5P8 ranges are described more frequently by color terms like boloshi 'white' and bajábaja 'dull'.

The term bajábaja is sometimes translated with 'grey', but is also linked to 'dirt', 'dust', and 'earth'. Bajábaja tipantalu does not describe the actual color of trousers, but is translated 'dirty, muddy trousers'. It can also be used to refer to the feathers of a bird that are a mix of grey, brown, and blackish tonality, or to the fur of some cats, and sometimes it describes the hair when it has spots of grey or white hairs. New Tribes Mission (1991, p. 16) accurately translates it with 'dusty; grey and white'. There is no identified non-reduplicated cognate. It seems that bajábaja in its natural context is used to designate a heterogeneous pattern of color, mixing gray, black or white. In the color test, bajábaja was often mentioned to describe stimuli with rather divergent distributions on the hue/brightness chart, its main referents coming from the dark-mid Yellow and Yellow/Red areas, and the light Blue/Purple area. As these two areas are not very similar, and as they are not well covered by the indigenous color-term system, the suspicion arises that bajábaja, as a color term, is sensitive to another parameter than hue or brightness. What it seems to relate to is the lack of purity of a color (an extension of its meaning 'dirty'). This parameter is usually expressed in terms of chroma (or intensity) in color theory, and it describes a continuum from a greyish variant of a color to a 'pure' representation of the color. The value of the chroma can be measured, and its value is indicated by the last number of a color code. However, the name bajábaja is assigned to colors with widely diverging chroma values. We will come back to this issue when discussing Table 3 below.

The adjective bombombo is almost exclusively used in La Misión (only once in Tres de Mayo). Even though it is also used in isolation, most occurrences of this term were in combination with another color term ( 44 out of 49 mentions). The main function of bombombo, therefore, seems to be to modify a color term. Bombo means 'smoke'. Ribera et al. (1991) list bombombo with the meaning 'tarnish (crystal)'. Bombombo titanti furthermore means 'to have clouded vision'. The literal meaning of bombombo seems to be 'clouded, smoke-like'; in relation to color, it means 'unclear, blurred, misty, clouded'. As it can appear with all kinds of colors, bombombo can be found across all hues, but mainly in the brighter regions. As expected, it surfaces relatively often in the underrepresented part of the bright area: Blue/Purple, and adjacent hues.

\subsection{The distribution of the Yurakaré color terms over color space}

Table 3 indicates how the color terms discussed so far are distributed over Munsell color space, in terms of the most common answers given to the stimuli of the color test. The rows represent the different hues, the columns different levels of brightness. For each area the percentage for the 'best answer' is given (in relation to the total number of answers for that particular stimulus. ${ }^{29}$

A few comments about this table are in place. First, the grey background indicates the areas where there was little agreement among consultants (under 25\%). Furthermore, the cells with the diagonal background patterns indicate cases where the difference between the most frequent answer and the second most frequent answer was less than $10 \%$. As can be seen, areas with a low degree of brightness are often not very codable. This might be due to the fact that hue-grounded color terms in Yurakaré have different brightness value extensions, as well as different brightness median points. Bubushi is a light color, as is kulákkula (however with some notable exceptions), itertere is a dark color, as is yënêjyënë (even though that does not become particularly clear from this table). Most hue-based color terms, however, do not extend to the darker areas. As a result, the darker zones tend to be areas of contention, as they are peripheral to most color term extensions, both hue-grounded and non-hue grounded, and thus can be rendered by several different color terms. The other zones of insecurity are in border

\footnotetext{
${ }^{28}$ Sometimes shëshëshë can have a meaning derived from shëshë 'bifurcation', e.g. Ana tësë shëshëshë banabanata kummë 'There is the tree with many branches.' Here, shëshëshë has the meaning of 'with ramifications', and is (in this example) synonymous with banabanata "with many branches". The more common form of 'having bifurcations' is shëshêshëshë.

${ }^{29}$ The table contains a number of loan words as most common answer. We will discuss these below in Sections 6.1-6.3.
} 
Table 4

Distribution of the answers for kape in Tres de Mayo and La Misión.

\begin{tabular}{|c|c|c|c|c|c|c|c|c|}
\hline & \multicolumn{4}{|c|}{ Tres de Mayo } & \multicolumn{4}{|c|}{ La Misión } \\
\hline \multirow{2}{*}{$\begin{array}{l}\text { Hue } \\
\downarrow\end{array}$} & \multicolumn{8}{|c|}{ Brightness $\rightarrow$} \\
\hline & 2 & 4 & 6 & 8 & 2 & 4 & 6 & 8 \\
\hline $\mathrm{R}$ & 5 & 1 & & & 7 & 1 & & \\
\hline YR & 3 & 1 & & & 10 & 15 & & \\
\hline Y & & & 1 & & 1 & 6 & 3 & \\
\hline GY & 2 & 1 & & & 1 & & & \\
\hline G & 1 & & & & & & & \\
\hline BG & & & & & & & & \\
\hline B & 2 & & & & & & & \\
\hline PB & & & & & & & & \\
\hline P & 3 & & & & & & 1 & \\
\hline RP & & & & & 1 & & & \\
\hline
\end{tabular}

Relative distribution of the answers:

\begin{tabular}{|l|l|l|l|}
\hline$<10 \%$ & $<20 \%$ & $<30 \%$ & $>30 \%$ \\
\hline
\end{tabular}

areas between two color terms: for example tëbêttëbë vs. kulákkula (10R6, 5RP6) itertere vs. kulákkula (10P6) sëjsëshi vs. itertere (5PB4). For the PB area there is also competition between itertere and yënêjyënë.

The differential distribution of color terms in terms of hue and brightness may also explain the peculiar distribution of bajábaja as a "best answer" in this table: at brightness 6 and 8 of 5PB, and at brightness level 4 of 5Y: brightness values that are not associated very strongly with the indigenous prototype for that hue area. This distribution, together with the translation given by consultants and the dictionary of the New Tribes Mission (see above) suggest that the term bajábaja relates to purity, but that purity in Yurakaré is a relative concept, depending on the prototypical distribution of each color term.

A further interesting aspect of Table 3 is that a number of color terms do not cover contiguous areas on the Munsell chart. There are various explanations for this situation. First, it reflects the competition in certain areas of very low (value 2) and very high (value 8 ) brightness values between hue-related and non-hue-related color terms. Furthermore, there seem to be only two color terms that have a highly concentrated focal area, where consultants agree with each other to a high degree: tëbêttëbë (91\% for 5R4), and sëjsëshi (96\% for $5 G 6$ and even 100\% for 10G4). The other color terms seem to designate hue areas in between these two focal areas, and thus have more competition from alternative terms for the same zone. ${ }^{30}$

The next Section discusses innovations (updates) in the color-term system of Yurakaré under the influence of Spanish. We distinguish three types of updating, which correlate with three different time periods. We term these three types of updating additive, restructuring, and substitutive updating. We will explain how they relate to the different historical periods in the corresponding Sections.

\section{The three phases of updating of the Yurakaré color-term system}

\subsection{Additive updating: new plants, new colors}

The first type of updating that can be distinguished in the data collected is the incorporation of older loans from Spanish. The best examples are kape, chujulati, and amaryu, and to a lesser extent añili. If we take into account the contemporaneous

\footnotetext{
30 There is a high degree of agreement among the consultants for some stimuli of bubushi 'yellow' (5Y8, 10Y8, 87\%). Nevertheless, the level of agreement is not comparable to sëjsëshi and tëbêttëbë. In contrast to those two colors, bubushi is associated with a color area outside its focal area much more often. This has been briefly discussed above, and we will come back to the issue below.
} 
Table 5

Distribution of the answers for chujulati in Tres de Mayo and La Misión.

\begin{tabular}{|c|c|c|c|c|c|c|c|c|}
\hline \multirow{3}{*}{$\begin{array}{l}\text { Hue } \\
\downarrow\end{array}$} & \multicolumn{4}{|c|}{ Tres de Mayo } & \multicolumn{4}{|c|}{ La Misión } \\
\hline & \multicolumn{4}{|c|}{ Brightness $\rightarrow$} & & & & \\
\hline & 2 & 4 & 6 & 8 & 2 & 4 & 6 & 8 \\
\hline $\mathrm{R}$ & 2 & & & 1 & 1 & & & \\
\hline YR & 4 & 6 & & 1 & & 1 & & \\
\hline $\mathrm{Y}$ & & 2 & & & & & & \\
\hline GY & & & & & & & & \\
\hline G & & & & & & & & \\
\hline $\mathrm{BG}$ & & & & & & & & \\
\hline B & & & & & & & & \\
\hline PB & & & & & & & & \\
\hline $\mathrm{P}$ & & & & & & & & \\
\hline RP & 3 & & & & & & & \\
\hline
\end{tabular}

Relative distribution of the answers :

\begin{tabular}{|l|l|l|l|}
\hline$<10 \%$ & $<20 \%$ & $<30 \%$ & $>30 \%$ \\
\hline
\end{tabular}

designation of these terms, and the historical conditions that have made their incorporation possible, we see that these words were molded within the structure of the indigenous system, and that they did not affect its general design. These terms partly cover areas of relative uncertainty, partly they are used as synonyms for terms that already existed before. The four terms in question are all derived from plant names known and used by the Yurakaré. Thus, they were incorporated into the classificatory system in the same way as indigenous color terms derived from plants (beymi, yënnë, itere, and shítiri). Moreover, these new loans are all secondary color terms (i.e. infrequently mentioned and not requiring derivational morphology), just as the other terms derived from plants (only itere is frequently mentioned).

This first type of updating occurred in a time when the Yurakaré speakers did not have very good competence in Spanish, and bilingualism was rare if present at all. Only through the plants or plant names that were introduced, the Spanish names could penetrate the Yurakaré system of classification. Even though it is not easy to fix a date for the first usages of these words in Yurakaré, we can infer the context in which they must have emerged. They coincided with a new phase in the history of the Yurakaré, marked by the repeated attempts of their conversion by Catholic missionaries, mostly Franciscans (1766-1820, but also in the 1850s). In spite of their attempts, however, the influence of missionary workers remained rather superficial: they never achieved complete settlement in missions of all Yurakaré people, and the missions could never be established in a permanent way. The increase of exposure to Spanish or Spanish words used by Quechua speakers was also due to the creation of a permanent commercial axis at that time, that united the Cochabamba valley and the ex-Jesuit missions in the Mojo plains. ${ }^{31}$

One indication that the aforementioned loans are older loans is that these terms have been adapted to Yurakaré phonology, a process we do not find in newer loans. The word kape has the Spanish input /ka 'fe/. Since /f/ is not a phoneme in Yurakaré, this sound is replaced by its closest counterpart: /p/. Furthermore, the Yurakaré variant has penultimate stress, whereas the Spanish source word has final stress. In Yurakaré lexical stress rules, final syllables may not be stressed, so this is also an adaptation to Yurakaré phonology. The Spanish input form for chujulati is / t f oko 'late/. The mid vowels /o/ and $/ \mathrm{e} /$ are raised to $/ \mathrm{u} /$ and $/ \mathrm{i} /$, respectively. This does not seem to be an adaptation to the phonological system of Yurakaré, given the fact that the language has mid vowels. Rather, it seems to be Quechuan influence. Quechua does not have any mid vowels, and Spanish mid vowels are consistently raised in Quechua. This particular point underlines the fact that chujulati is an early loan. The major part of the Spanish-speaking community with which the Yurakare had contacts in the late 18th and

\footnotetext{
31 See Rodríguez Ostria (1997), De la Fuente (n.d. [2000]).
} 
Table 6

Distribution of the answers for amaryu in Tres de Mayo and La Misión.

\begin{tabular}{|c|c|c|c|c|c|c|c|c|}
\hline & \multicolumn{4}{|c|}{ Tres de Mayo } & \multicolumn{4}{|c|}{ La Misión } \\
\hline \multirow{2}{*}{$\begin{array}{l}\text { Hue } \\
\downarrow\end{array}$} & \multicolumn{8}{|c|}{ Brightness $\rightarrow$} \\
\hline & 2 & 4 & 6 & 8 & 2 & 4 & 6 & 8 \\
\hline$R$ & & & & 1 & & & & \\
\hline YR & & 1 & 2 & 2 & & & & \\
\hline $\mathrm{Y}$ & & & 2 & 3 & & & & \\
\hline \multicolumn{9}{|l|}{ GY } \\
\hline \multicolumn{9}{|l|}{ G } \\
\hline \multicolumn{9}{|l|}{ BG } \\
\hline \multicolumn{9}{|l|}{ B } \\
\hline \multicolumn{9}{|l|}{ PB } \\
\hline \multicolumn{9}{|l|}{$P$} \\
\hline $\mathrm{RP}$ & & & & & & & & \\
\hline
\end{tabular}

Relative distribution of the answers :

\begin{tabular}{|l|l|l|l|}
\hline$<10 \%$ & $<20 \%$ & $<30 \%$ & $>30 \%$ \\
\hline
\end{tabular}

19th centuries originated from the Cochabamba valley, and was generally fluent in Quechua as well. ${ }^{32}$ The lenition of postvocalic $/ \mathrm{k} /$ to $/ \mathrm{h} /$, written $j$, is a phonological rule of Yurakaré. The final term, amaryu, has as its input /ama ' $r i \varsigma \circ /$. As a result of the iambic footing pattern of Yurakaré, stress shifts to the second syllable from the left, and consequently, the penultimate, unstressed syllable is elided. Furthermore, the palatalized lateral is replaced with the semivowel /j/, written $y$, and the final vowel is raised.

The results from Tres de Mayo and La Misión show that kape and chujulati should be studied separately from amaryu. In fact, kape and chujulati occur in similar color ranges, partially left empty by the original classification system, whereas amar$y u$ occurs in the area covered by bubushi. Moreover, the historical processes that have led to the incorporation of the different terms were not the same, nor were the semantic operations that went with the incorporation of the terms. In their current usage by the Yurakaré, kape and chujulati cover a specific area in the Munsell spectrum: the ranges of R and YR (and to some extent Y in La Misión, particularly in the lower brightness areas. Regarding hue, the results are coherent for La Misión and Tres de Mayo, but with two major differences. In the case of kape, in La Misión its usage in the R and YR and Y ranges is more frequent than in Tres de Mayo. Moreover, in Tres de Mayo occurrences in other hue ranges (GY, G, B, and P) are not only possible but also relatively frequent. The word chujulati on the other hand is almost exclusively found in Tres de Mayo: 19 responses vs. 2 in La Misión. With this term, we find the focus of usage in the YR $(2,4)$ range, a result that correlates with the 2 answers in La Misión (R2 and YR4). The distributions of kape and chujulati are shown in Tables 4 and 5.

Especially in Tres de Mayo, and to a lesser degree in La Misión, kape is in competition with color terms not sensitive to hue, such as wuriwurishi, shüjshüshi, and shëshëshë. As contact with Spanish was less intense in Tres de Mayo than in La Misión, we can infer that kape was used as a synonym for some of these words, with a weak preference for the YR and adjacent ranges. This situation can be explained with the structural properties of the Yurakaré color classification where, in the ranges of low brightness, terms that are not sensitive to hue can be used with a relative degree of liberty. The strong correspondence between kape and shëshëshë is corroborated by the fact that the latter term is often translated with Spanish 'café' (cf. New

\footnotetext{
32 The following interesting complaint of the governor of the Santa Cruz intendancy, Francisco de Viedma, shows the importance of Quechua at the end of the 18th century, including in the city of Cochabamba: "Entre la gente vulgar no se habla otro idioma que el quichua, y aun entre las mujeres decentes hay muchas que no se saben explicar en castellano" (1836 [1783], pp. 14-15) [Among the vulgar people, no other language is spoken than Quechua, and even among decent women there are many that cannot make themselves understood in Spanish - our translation]. The widespread diffusion of Quechua in non-indigenous or peasant societies, as well as in the ones talked about by de Viedma, declined only after the revolution of 1952.
} 
Table 7

Distribution of the answers for sëjsëshi in Tres de Mayo and La Misión.

\begin{tabular}{|l|l|l|l|l|l|l|l|l|l|}
\hline \multicolumn{2}{|l|}{ Tres de Mayo } \\
$\downarrow$
\end{tabular}

Relative distribution of the answers:

\begin{tabular}{|l|l|l|l|}
\hline$<3 \%$ & $<6 \%$ & $<9 \%$ & $<12 \%$ \\
\hline
\end{tabular}

Tribes Mission, 1991, p. 100). The concentration of the responses for kape in La Misión is due to a different type of updating that followed its initial adaptation, which we will explain below.

In the case of chujulati, the situation is somewhat different. While in Tres de Mayo there is a concentration mainly in the low brightness values in the ranges of R, YR, Y, and RP, it may be considered almost a relic in La Misión. It is not clear why this word is not really present in La Misión, and the results as they are do not suggest an interpretation.

The early incorporation of kape and chujulati in the color terminology of Yurakaré goes beyond a mere transformation of the stock of domesticated plants they managed. We know that both plants reached the Yurakaré territory with the first missionaries. Rodríguez (1789), one of the first non-religious colonizers of the Chapare area, makes the following comment: "es constante, que de la reduccion de los Yuracarees a Nuestra Santa fee, [...] ha resultado el [...] logro de muchos terrenos fertiles, que ya produzen coca, cacao, café y otras muchas frutas." ${ }^{33}$

The coffee and chocolate plants are still used by the Yurakaré. The chocolate tree in particular has a wide area of diffusion, although it is probably more common in the Sécure area, and it is also used for commercial purposes. Coffee also still exists, but is much less common. Even though it is difficult to say when these terms actually start to denote colors, it is important to emphasize that this usage is probably derived from Spanish, where these two names also have a color dimension. Even though the usage of the Yurakaré terms is based on the Spanish usage, its integration was facilitated by the combination of plant and color, as is common in the indigenous system. The only innovation within the system here is that the plant from which the color term is derived is not used to produce traditional dyes.

The case of amaryu is different from the two cases described above. This term was exclusively found in Tres de Mayo, where it was used by only four consultants, and it was never the most frequent term for a particular color. However, it shows a coherent distribution in the lighter YR and Y ranges, as can be seen in Table 6.

There is a strong correlation between amaryu and bubushi (for the distribution of bubushi, see Table 10 below). One consultant systematically answered amaryu(mashi) where other speakers responded with bubushi(mashi). However, the low frequency of its occurrence in Tres de Mayo and its absence in La Misión (even though the plant is known in both communities) show that this term is particularly peripheral. In contrast to chujulati and kape, which appear in an area not sensitive to hue, amaryu is a duplication of the original term for 'yellow' bubushi, integrated in an area of the spectrum that was already

\footnotetext{
33 "It is a fact that the conversion of the Yurakare to our Holy Faith has resulted in the development of many fertile terrains, which produce coca, cacao, coffee, and many other fruits." (our translation).
} 
Table 8

Distribution of the answers for seleste, asúl, shítiri, and winuyle in Tres de Mayo and La Misión.

\begin{tabular}{|c|c|c|c|c|c|c|c|c|c|c|c|c|}
\hline & \multicolumn{5}{|c|}{ Tres de Mayo } & \multicolumn{7}{|c|}{ La Misión } \\
\hline Hue & \multicolumn{12}{|c|}{ Brightness $\longrightarrow$} \\
\hline$\downarrow$ & 2 & \multicolumn{2}{|l|}{4} & 6 & 8 & 2 & \multicolumn{2}{|l|}{4} & \multicolumn{2}{|l|}{6} & \multicolumn{2}{|l|}{8} \\
\hline \multicolumn{13}{|l|}{$\mathrm{R}$} \\
\hline \multicolumn{13}{|l|}{ YR } \\
\hline $\mathrm{Y}$ & & & & & & 1 & \multicolumn{2}{|l|}{2} & \multicolumn{2}{|l|}{3} & & \\
\hline GY & & \multicolumn{2}{|l|}{2} & 1 & & 1 & \multicolumn{2}{|l|}{1} & \multicolumn{2}{|l|}{3} & \multicolumn{2}{|l|}{1} \\
\hline G & 1 & \multicolumn{2}{|l|}{1} & & & 1 & & & \multicolumn{2}{|l|}{1} & \multicolumn{2}{|l|}{1} \\
\hline BG & 1 & \multicolumn{2}{|l|}{1} & 2 & & 3 & 2 & 1 & 3 & 2 & 1 & 1 \\
\hline B & 1 & \multicolumn{2}{|l|}{1} & 1 & 1 & 4 & 6 & 2 & 5 & 5 & 3 & 3 \\
\hline PB & 1 & $\overline{1}$ & 1 & 2 & 2 & 5 & \multicolumn{2}{|l|}{6} & 2 & 2 & 1 & 2 \\
\hline $\mathrm{P}$ & & \multicolumn{2}{|l|}{1} & & 1 & 1 & & & & & & \\
\hline $\mathrm{RP}$ & & & & 1 & 1 & & & & & & & \\
\hline
\end{tabular}

Representation of the colors:

\begin{tabular}{|l|l|l|l|}
\hline seleste & winuyle & shítiri & asúl \\
\hline
\end{tabular}

covered. Even though the term amaryu was probably maintained as a specific kind of bubushi as long as a yellow dye was being produced from the plant, this was not the case in the whole Yurakare territory. In the places where the term is now still used, like in Tres de Mayo, it seems to be supported by its proximity to Spanish amarillo 'yellow', which may be a factor of re-motivation.

The factors that permitted the incorporation of this color term deserve some comments. Amaryu is the name of a plant from which the Yurakaré extracted a yellow-orangey color which they used to decorate their traditional beaten barkclothes. Both the name of the plant and its use for the production of dye are already mentioned in the beginning of the 19th century, showing the time depth of this loan word. Around 1810, Lacueva wrote that the Yurakaré produce the color "(...) amarillo con un bejuco y unas papas que llaman 'amarillo'." ${ }^{34}$ Boria, inspired by his predecessor, some years later wrote that the yellow dyes were made of "un bejuco i unas papas que sin duda adquieren de otras gentes, pues [los Yurakaré] los [sic.] llaman amarillo." ${ }^{35}$ Even though we cannot yet be certain without a scientific identification, the amaryu plant might correspond to one of the various species of plants used for the production of dyes called 'curcuma' or 'palillo' in Bolivian Spanish, from the rhizome of which a yellow-orangey color can be extracted. ${ }^{36}$

Thanks to Boria (1897 [1820]) we know that non-cultivated palillo plants could be found along the San Mateo river, an upper tributary of the Chapare river in the beginning of the 19th century. Mendoza and Mendoza (1893) mention a list of plants used by the Yurakaré from Moleto (between the Sécure and Isiboro rivers) to produce dyes, saying that they have a yellow dye won from a plant they call 'curcuma'. ${ }^{37}$ This all suggests that the plant amaryu got its name (and maybe its usage) from a transfer of knowledge from speakers of Spanish or Spanish-Quechua bilinguals to the Yurakaré, possibly with the interference of Quechua kellu kaspi. This possibility suggests two historical options: (i) amaryu was not known

\footnotetext{
34 “(...) yellow from a creeper and some bulbs they call 'amarillo' ” (Cited in Priewasser, 1916-1920, [10 (120)], p. 446).

35 “( ...) a creeper and some bulbs that they undoubtedly get from other people, the Yurakaré call them 'amarillo”' (Boria, 1897 [1820]).

36 The real curcuma (Curcuma longa) originates from Asia and is called curcuma or palillo in Bolivia (Sanez Mamani, 1992). Escobedia grandifolia, a local plant, is known as palillo in the area of Santa Cruz de la Sierra (cf. Weddell, 1853, p. 70, Nee: http://www.nybg.org/botany/nee/ambo/Checklist/ast1.html). De Lucca Dröxler (2004, p. 129) indicates that this species is called palillo, curcuma, or azafran in Bolivia. Finally, Escobedia cabrifolia is a plant cultivated in the Yungas of La Paz called palillo in Spanish and kellu kaspi 'yellow stick' in Quechua (Girault, 1984).

37 "Itira [itere], tiñe el morado en fresca, y el café en seca. - Cancarce [kankashi], da un rojo vivo. - Yene [yënnë], da el negro brilliante.- Curcuma, para el amarillo. (our corrections)" ["Itere dyes purple when fresh, and coffee when dry. - Kankashi gives a lively red. - Yënnë, gives a brilliant black. - Curcuma is for yellow."] (Mendoza and Mendoza, 1893, p. 25).
} 
Table 9

Distribution of the answers for kulákkula in Tres de Mayo and La Misión.

\begin{tabular}{|c|c|c|c|c|c|c|c|c|}
\hline & \multicolumn{4}{|c|}{ Tres de Mayo } & \multicolumn{4}{|c|}{ La Misión } \\
\hline \multirow{2}{*}{$\begin{array}{l}\text { Hue } \\
\downarrow\end{array}$} & \multicolumn{8}{|c|}{ Brightness $\longrightarrow$} \\
\hline & 2 & 4 & 6 & 8 & 2 & 4 & 6 & 8 \\
\hline $\mathrm{R}$ & 3 & 1 & 3 & 5 & 1 & 1 & 9 & 8 \\
\hline YR & 1 & & 2 & 3 & & & 5 & 3 \\
\hline Y & & 1 & 1 & & & & & \\
\hline GY & & & 1 & & & & & 1 \\
\hline G & & & & 1 & & & 1 & 1 \\
\hline BG & & 1 & 2 & 2 & & & & 1 \\
\hline B & 3 & 1 & 3 & & & & & \\
\hline PB & 1 & 2 & 2 & 2 & & & & 1 \\
\hline$P$ & 2 & 3 & 7 & 2 & & 1 & 1 & 9 \\
\hline $\mathrm{RP}$ & 1 & 2 & 5 & 5 & 1 & 4 & 7 & 10 \\
\hline
\end{tabular}

Relative distribution of the answers :

\begin{tabular}{|l|l|l|l|l|}
\hline$<3 \%$ & $<6 \%$ & $<9 \%$ & $<12 \%$ & $>12 \%$ \\
\hline
\end{tabular}

historically to the Yurakaré, and was introduced by other people, and (ii) it was already known but renamed on the basis of a metonymy between the color and the dye.

We can possibly add one more ancient loan to the aforementioned terms: añili. This form, in spite of its diffusion throughout the Sécure area as a color term, was only mentioned by one consultant in Tres de Mayo on five occasions. This term is restricted to the BG range and is derived from Spanish añil, the name for indigo and for the plant called shitiri by the Yurakaré. Interestingly, the same consultant that used añili was also one of the most frequent users of the term shitiri (10 times). This suggests a distinction between the denomination of the two terms for this speaker. Even though there is an overlap in the hue areas associated with the terms by this speaker, añili seemed to have a more restricted interpretation (BG, B) than shítiri (BG, B, PB, and one GY). Here we possibly have a competition between two words which denote the same thing, and a speaker who attributes the different forms to different ranges. In La Misión, we also found a term añili, also a loan from Spanish, connected to the domain of colors but not connected to shitiri, as this word is no longer known there either as a plant, or as a color term, but only as a name for birthmarks. In La Misión, añili is used for certain paints with a high degree of saturation that could be bought in the market in a near past. It seems possible that this word derives from colores de anilina 'aniline dyes' (Bol. Sp. añelina). Aniline was originally the name for a byproduct of carbon from which the dyes were extracted. Añelina dyes were very common in the Bolivian Andean area where it served especially for painting wool with more lively colors than the natural ones.

\subsection{Restructuring updating: specialization and recent loans}

The second type of updating is quite different from the first one, described above. Where in the first type terms are incorporated by means of the concrete mediation of new botanical knowledge, without having an impact on the system as a whole, the second type leads to an inner abstract adjustment of the scope of some indigenous terms, which is the result of a more accurate knowledge of the Spanish color nomenclature.

These adjustments, which operate mostly at the hue level, manifest themselves in two ways: (i) the adoption of classificatory criteria present in Spanish, but not in Yurakaré, (ii) the decrease of the scope of an indigenous color term, or of the frequency a term is used for a certain color range, and its concentration around a focal area similar to the Spanish classification. These two processes clearly point out the difference between this and the previous type of updating. The second type of adjustment goes hand in hand with the incorporation of new color terms, and it leads the Yurakaré system to converge with the system of Spanish. 
Table 10

Distribution of the answers for bubushi in Tres de Mayo and La Misión.

\begin{tabular}{|c|c|c|c|c|c|c|c|c|}
\hline & \multicolumn{4}{|c|}{ Tres de Mayo } & \multicolumn{4}{|c|}{ La Misión } \\
\hline \multirow{2}{*}{$\begin{array}{l}\text { Hue } \\
\downarrow\end{array}$} & \multicolumn{8}{|c|}{ Brightness $\rightarrow$} \\
\hline & 2 & 4 & 6 & 8 & 2 & 4 & 6 & 8 \\
\hline $\mathrm{R}$ & & 2 & 8 & 5 & & & 2 & 4 \\
\hline YR & & 4 & 19 & 14 & 1 & & 12 & 15 \\
\hline Y & & & 5 & 21 & & & 7 & 19 \\
\hline GY & & & 1 & 6 & & & & 3 \\
\hline G & & & & 1 & & & & \\
\hline BG & & & 1 & 1 & & & & \\
\hline B & & 1 & 1 & 1 & & & & \\
\hline PB & & & 1 & & & & & \\
\hline P & 1 & 1 & 2 & 2 & & & & \\
\hline RP & & 1 & 1 & 3 & & & & 1 \\
\hline
\end{tabular}

Relative distribution of the answers:

\begin{tabular}{|l|l|l|l|l|}
\hline$<3 \%$ & $<6 \%$ & $<9 \%$ & $<12 \%$ & $>12 \%$ \\
\hline
\end{tabular}

Table 11

The distribution of creative terms.

\begin{tabular}{|c|c|c|c|c|c|c|c|c|}
\hline \multirow[t]{3}{*}{ Hue $\downarrow$} & \multicolumn{8}{|c|}{ Brightness $\rightarrow$} \\
\hline & \multicolumn{4}{|c|}{ Tres de Mayo } & \multicolumn{4}{|c|}{ La Misión } \\
\hline & 2 & 4 & 6 & 8 & 2 & 4 & 6 & 8 \\
\hline \multicolumn{9}{|l|}{$\mathrm{R}$} \\
\hline YR & & & bubujshëtë & kuynari & & & & \\
\hline $\mathrm{Y}$ & & eleshi dyulula pëlëshi & shüpshü abuba & bubujshëtë & & si tapëlëshi & & \\
\hline GY & & soleyleshi (2 times) & & soleyleshi & & shajshashi & & \\
\hline G & & soleyleshi & soleyleshi & & & & & \\
\hline \multicolumn{9}{|l|}{ BG } \\
\hline B & & & ashaashi & sandiashi & & & kudashimashi & \\
\hline PB & & shecheshi & & & & & & \\
\hline $\mathrm{P}$ & & shecheshi & tajibo abuba & & & & nawashi & \\
\hline $\mathrm{RP}$ & & & & & & & & \\
\hline
\end{tabular}

It is difficult to situate the beginning of this type of updating. Broadly speaking, these changes took place throughout the 20th century with a strengthening of the colonization of the Yurakare territory, slower in some places (like the IsiboroSécure region), faster in others (like the Chapare region). This general change in the situation of the Yurakaré led to a growing competence in Spanish, and to a growing number of bilinguals with similar proficiency in Yurakaré and Spanish. This situation was facilitated by two developments. First, Spanish-speaking schools were progressively implemented. La Misión, created at this time as a Franciscan mission with a boarding school, is a case in point. ${ }^{38}$ After the retirement of the missionary workers, at the beginning of the 1920s, the government created an educational unit in La Misión that has functioned as such from the 1940 s until the present, without much interruption. ${ }^{39}$ Tres de Mayo was founded much later, in the 1980 s, at a time

\footnotetext{
38 Miller (1918, p. 305), give some comments about the Yurakaré mission school when the mission was situated at the Chimoré river, before it moved to the Chaparé in 1916. (cf. also Rodríguez Ostria, 1997, pp. 89-90).

39 Pérez (1962, pp. 274-278) and personal communication of elder local people.
} 
Table 12

Translation of creative terms.

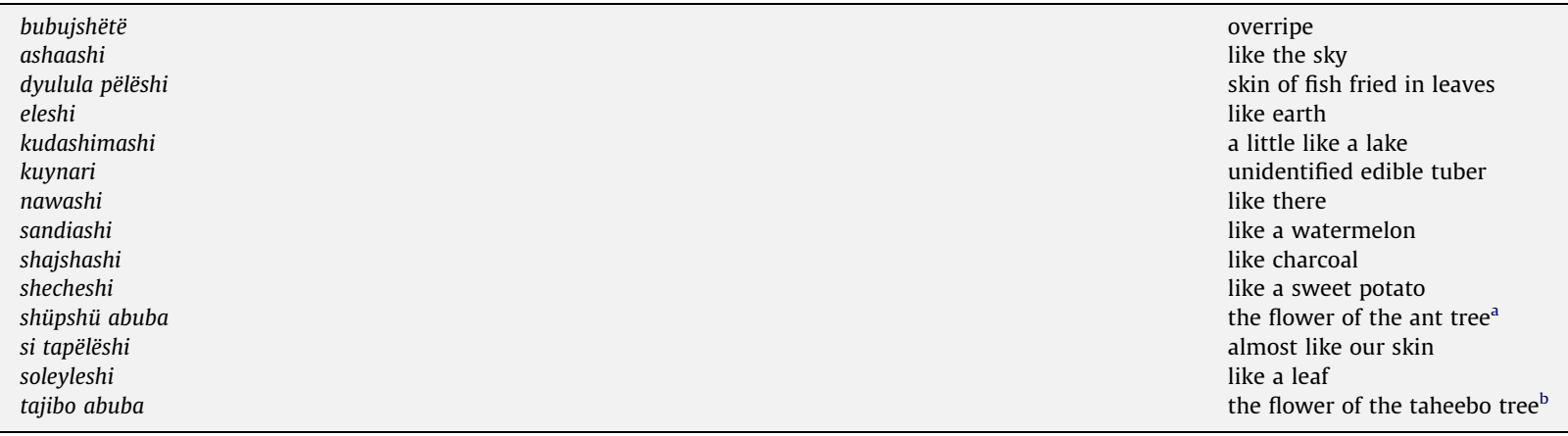

a Triplaris americana.

b Tabebuia impetiginosa.

when it was government policy to create primary schools in rural areas to make education more accessible. Currently, many parents, especially in the Isiboro-Sécure region, do not want their children to learn Yurakaré because they still remember how they were punished themselves for speaking it. Another important development in the 20th century is the increase of new opportunities for paid labor. The Yurakaré, especially of the Chapare River, offered their services as laborers with increasing frequency to Spanish-speaking employers, who hired them as e.g. fluvial transporters, lumberjacks, or cowboys. During the (often long-term) stays of Yurakare at the work site, the language of communication was generally Spanish.

As an example of the decrease of the scope of a color term, we will discuss the case of sëjsëshi. The results of the Munsell test show its distribution in the GY, G, BG, and B domains, with diffuse extensions to PB and Y (see Table 7).

The relatively coherent distribution in both communities allows us to infer a continuity of usage of the original scope of this term, translated by Lacueva as 'green' and 'blue' (Adam, 1893). However, even though speakers still associate sëjsëshi with the $\mathrm{B}$ range and part of the $\mathrm{PB}$ range, the denotatum of the color term has specialized further towards green, at the cost of blue. This specialization goes hand in hand with the introduction of (mainly) Spanish terms predominantly in the B range, reinforcing the contrast between blue and green. Thus, the distinction between blue and green in the classificatory system of Yurakare is a contact-induced addition to the indigenous system.

In the original system, it is very probable that the prototypical value of sëjsëshi was in the G range, the coverage of the B range being an extension of the term. The fact that the loanwords are terms of the B range suggests that the original term was a $G$ prototype with a B periphery; otherwise, the loanwords would have come from the $G$ area. This point is confirmed by the translation of sëjsëshi with 'green' rather than 'blue', when speakers are asked to translate the term. In addition, the maximal concentration of sëjsëshi is in the $\mathrm{G}$ range in both communities, with different distributions in GY and BG. For that reason, the introduction of the distinction made in Spanish between blue and green into Yurakaré led to a demotivation of the use of sëjsëshi for the peripheral B areas, and opened the path for new loan words. This process of reduction of the original scope of the term sëjsëshi is confirmed by the results for other color terms relating to the BG range, which overlap mostly with the peripheral uses of sëjsëshi (see Table 8).

Table 8 presents the results for the loanwords seleste ( $>$ Sp. celeste) and asúl ( $>$ Sp. azul), and for two words of Yurakaré origin, one of the historic stock, shitiri, the other a more recent innovation, winuyle (with the variants winnushi, winnu, winnushkuta, winnu ayle). The latter term was only reported in La Misión. The pair seleste and asúl clearly are recent loans in relation to the historic loans discussed above. The term asúl has not been phonologically adjusted: it takes word-final stress, normally disallowed in Yurakaré, and it ends in a consonant that cannot occur in coda position in Yurakaré. Another factor that points to these two terms being recent loans is the low frequency of both terms in Tres de Mayo.

Table 13

Recent loans.

\begin{tabular}{|c|c|c|c|}
\hline Spanish loan & Source & Tres de Mayo & Misión \\
\hline amarillu & >Spanish amarillo, 'yellow' & $\times$ & $\times$ \\
\hline anaranjaw, naranja & >Local Beni Spanish anaranjaw, transformation of anaranjado, 'orange' & $\times$ & $\times$ \\
\hline byoleta & >Spanish 'violeta', violet & & $\times$ \\
\hline choko & >Local spanish 'choco' especially for chestnut-colored hair. & $\times$ & $(\times)^{\mathrm{a}}$ \\
\hline gindo & >Spanish guindo, 'dark purple' & & $\times$ \\
\hline lila & >Spanish lila, 'lilac' & & $\times$ \\
\hline mayaw & >? Quechua maywa, 'violet' & & $\times$ \\
\hline moraw & >Local Beni Spanish moraw 'purple', transformation of Sp. morado. & $\times$ & \\
\hline polomo/plomo & >Spanish plomo 'gray' & $\times$ & $\times$ \\
\hline
\end{tabular}

a This term is actually used in La Misión but did not occur in the color test. 
In fact, the emergence of asúl and seleste with a different distribution and frequency in the two communities can be considered symptomatic for the process of reanalysis of the scope of the term sëjsëshi. In Tres de Mayo, asúl concentrates on dark hues (value 2/4) of PB and B, but also P. Even though it partly overlaps with the distribution of azul in Spanish, the lighter versions of $\mathrm{B}$ are often denoted by shitiri, a color term that partly overlaps with sëjsëshi, but also occurs independently in the PB domain not covered by sëjsëshi (value 6 and 8 ).

In Tres de Mayo, the term seleste is used only for bright color values, and it does not seem to be connected to the B range, but to the P and RP domains, so its focus does not overlap with the Spanish focus of celeste. In La Misión, in contrast to Tres de Mayo, all the answers seleste are in the BG, B, and PB ranges (with one exception: P at brightness level 2). Asúl is used for all the brightness values of the B range, from the brightest to the darkest. The fact that in La Misión, the hues BG, B, and, to a lesser degree, PB, all receive answers sëjsëshi can in part be attributed to the application of the test: consultants in La Misión, in contrast to those in Tres de Mayo, were explicitly asked to name the colors in the indigenous language. For this type of colors, it occurred very often that consultants spontaneously named them with one of the Spanish terms asúl or seleste, and after a longer reflection gave as an equivalent sëjsëshimashi 'sort of sëjsëshi'. In other words, the quantity and distribution of seleste and asúl in the two communities represent two different phases of an increasing sensibility to the green-blue contrast taken from Spanish. In Tres de Mayo, these loans are not very common and they have a usage that is different from the original terms, but with these terms becoming more known, like in La Misión, they converge towards the prototypes of the source terms, provoking a retreat of sëjsëshi towards more strictly green hues, leaving the blue hues to the loanwords.

Table 8 also shows another interesting fact: the contrast between the term shítiri as used in Tres de Mayo and the term winuyle in La Misión. As discussed above, the shitiri plant and the dye it produces are known in Tres de Mayo but not in La Misión. The loss of shítiri has thus facilitated the adoption of Spanish celeste and azul in La Misión but not in Tres de Mayo. Winuyle (leaf of the chili pepper plant) corresponds to a relatively homogeneous range in the Y, GY, and G area. The name is a creative invention with a local concentration restricted to some consultants of the same family from La Misión, not appearing in others. Moreover, this term is consistently translated as 'verde lechuga' (salad green) to Spanish. It therefore seems plausible that winuyle is an invention in the Yurakaré language to translate a color distinction from Spanish, using at the same time the resources from the language itself, but also the cultural knowledge of local plants.

There are more cases where we note a reduction of the scope of indigenous terms, including a shift toward a prototype similar to the Spanish equivalent. When we compare the results from Tres de Mayo with la Misión, the most important cases are kulákkula and bubushi (see Tables 9 and 10). On the one hand, in the community most exposed to Spanish influence (La Misión), one can observe a decrease of the number of stimuli designated with bubushi and kulákkula, and on the other hand the increase of the relative proportion of answers situated in the hue area that is the focal area for the Spanish term generally given as a translation by the speakers, rosado (pink) for kulákkula and amarillo (yellow) for bubushi.

As Table 9 shows, the distribution of kulákkula in Tres de Mayo extends almost across the whole range of colors, mostly with low relative frequency. This does not point to a 'lack of knowledge' of the features of this word, but rather to the fact that kulákkula is not defined entirely by hue, in spite of its attestation as a hue term since the beginning of the 19th century. This is confirmed indirectly by the data from La Misión, where we also find isolated answers of kulákkula in the ranges of GY, G, and BG. The higher concentration of the term in La Misión in the lighter R, RP, and P areas is a clear effect of the convergence of the term towards a prototype corresponding to Spanish rosado (pink), a term that is commonly used to translate kulákkula in La Misión. In this case, the connection between kulákkula and ajula 'ripening' (i.e. a fruit being in the process of acquiring its definitive color) has faded, in favor of a growing sensitivity to hue and brightness. The specialization of this term is partly conditioned by its position relative to the other principal color terms. In the range of 'pink' it comes to occupy an area where there was a relative uncertainty in the indigenous terminology (see Table 3 above).

Although less clear than kulákkula, bubushi 'yellow' illustrates another case of the process of shift towards a Spanish-derived prototype. We observe a decrease of the range of occurrences, and at the same time an increase of the concentration of answers around a particular focus (see Table 10):

In contrast to kulákkula, the focal area of bubushi is the same in both communities, but with a higher frequency of answers around this focus in La Misión. The possibility of using bubushi beyond the range of YR and Y (essentially due to the expression bubushimashi 'sort of bubushi') diminishes, and the mentions of bubushi with values corresponding to red (R6) and green-yellow (GY6) decrease or disappear. In the case of green-yellow, it is probable that the presence of winuyle in La Misión reinforces the use of bubushi for values more strictly concentrated around the hues YR and Y.

\subsection{Substitutive updating: attrition and loss of the indigenous color classification and terminology}

The last step in the updating process of the Yurakare color-term system is the loss of some of the indigenous terms and classificatory criteria, and possibly the eventual loss of the entire system. Even though all indigenous color terms recorded by Lacueva in the beginning of the 19th century are still in use in both communities, certain terms are in the process of falling out of use, and the productivity of the system is gradually decreasing. This process is connected to the increase of the use of Spanish in day-to-day conversation, going hand in hand with a shift from Yurakaré to Spanish as the dominant language.

Whereas the generation around forty years of age still acquired Yurakaré as their first language and learned Spanish especially in an intercultural context, the children now mostly learn Spanish in a family context as their first language, supplemented with school education. These children probably will not acquire any active knowledge of Yurakaré at all. The generation in between have grown up with both languages, but the younger they are, the more dominant is the Spanish 
Table 14

Distribution of answers for moraw, byoleta and mayaw.

\begin{tabular}{|c|c|c|c|c|c|c|c|c|c|c|c|c|c|c|c|}
\hline \multirow{3}{*}{\begin{tabular}{|l} 
\\
Hue \\
$\downarrow$ \\
\end{tabular}} & \multicolumn{4}{|c|}{ Tres de Mayo } & \multicolumn{11}{|c|}{ La Misión } \\
\hline & \multicolumn{15}{|c|}{ Brightness $\rightarrow$} \\
\hline & \multirow{2}{*}{\begin{tabular}{|l|}
2 \\
1
\end{tabular}} & \multirow[t]{2}{*}{4} & \multirow[t]{2}{*}{6} & \multirow[t]{2}{*}{8} & \multicolumn{4}{|l|}{2} & \multicolumn{3}{|l|}{4} & \multicolumn{3}{|l|}{6} & \multirow[t]{2}{*}{\begin{tabular}{|l|l}
8 \\
l
\end{tabular}} \\
\hline $\mathrm{R}$ & & & & & $\overline{1}$ & 1 & & 1 & & & & & & & \\
\hline \multicolumn{16}{|l|}{$\begin{array}{l}\mathrm{YR} \\
\end{array}$} \\
\hline \multicolumn{16}{|l|}{ Y } \\
\hline \multicolumn{16}{|l|}{ GY } \\
\hline \multicolumn{16}{|l|}{$G$} \\
\hline BG & & & & & & & & & 1 & & & & & & \\
\hline \multicolumn{16}{|l|}{ B } \\
\hline PB & 2 & & & & 1 & & 1 & & & & & 1 & 1 & & \\
\hline$P$ & 2 & & & & 1 & & 2 & & 4 & 2 & 2 & 2 & & 1 & \\
\hline $\mathrm{RP}$ & 1 & & & & 1 & 3 & 1 & 1 & 1 & & & & & & \\
\hline
\end{tabular}

moraw byoleta mayaw gindo lila

language, leading to a general gradual loss of proficiency. Speakers with Spanish as their dominant language have the Spanish color-term system more available than the Yurakaré system. As a result, they are insecure about the color terms of the indigenous language, and prefer to use the Spanish terms.

Comparing the results from the two villages under investigation, the symptoms of the gradual loss of the color system are reflected in the data in two ways: (i) a clear decrease of the creative use of the language to form ad hoc color terms, (ii) an increase of the availability of the Spanish color term inventory, which each individual speaker can use at their leisure.

As noted in Section 5, some of the conventionalized color terms in Yurakaré are lexicalized forms derived from nouns with the similative suffix -shi, like bubushi and sëjsëshi. This derivational device can also be used to create new terms. Furthermore, ad hoc color terms can be formed by using names or expressions that refer to objects with a salient color, without any derivational marking. Speakers draw on these creative operations in three different cases: to name colors that are not covered by conventionalized terms, to name colors for which the term is temporarily irretrievable, or to capture a more specific hue-reference than that of the conventionalized term. The absence of creative terms in the darker areas (brightness 2 ) seems to show that creativity is mostly linked to hue. This is not so clearly the case in lighter areas (brightness 8 ) in Tres de Mayo, but this may be due to the fact that hue is perceptively more salient in the light areas that in the darker ones. All creative responses given to the stimuli are shown in Table 11, the translations of the terms are given in Table 12.

The type of response in this category corresponds generally to a "poetical" way of designating colors, linking them to the color properties of pertinent natural scenery or objects (landscape, flowers, fruits, etc.), or to processes, like bubujshëtë whose meaning 'yellowing, e.g. of leaves or fruit' is reminiscent of color terms like kulákkula and bubushi. We also encountered pragmatic solutions, like the use of a deictic in the case of nawashi, "like there". Here the consultant designated a point of his environment, because he could not name the color directly. Even though some terms occur more than once (e.g. soleyleshi 'like a leaf', shecheshi 'like a sweet potato'), they are not shared by a wide range of consultants (most repetitions come from one and the same person). This shows that they were ad hoc creations, and not conventionalized color terms. ${ }^{40}$

The frequency of creative terms is much lower in La Misión than in Tres de Mayo; rather than imagining ad hoc indigenous solutions, the consultants from La Misión tend to either use a Spanish term, or not to give an answer at all. ${ }^{41}$ This kind of attrition of creative language usage suggests an impoverishment of a linguistic system. It shows that, in contrast to Tres de

\footnotetext{
40 Of course, such a creative process may lead to the emergence of new color terms, as possibly is the case for winuyle; the five occurrences of soleyleshi might suggest a development towards an alternative term for the GY and G area.

41 The reader is reminded that giving Spanish terms was not given as an option to the consultants in La Misión.
} 
Table 15

The different dimensions of updating.

\begin{tabular}{|c|c|c|c|c|}
\hline & $\begin{array}{l}\text { Historical } \\
\text { period }\end{array}$ & Sociolinguistic situation & Linguistic treatment & Effect on indigenous system \\
\hline Additive & $\begin{array}{l}\text { End 18th- } \\
\text { beginning 20th } \\
\text { century }\end{array}$ & $\begin{array}{l}\text { Low degree of contact and } \\
\text { bilingualism }\end{array}$ & $\begin{array}{l}\text { Borrowed forms adapted to Yurakaré } \\
\text { structure and classification }\end{array}$ & Little effect \\
\hline Restructuring & 20th Century & $\begin{array}{l}\text { High degree of contact and } \\
\text { bilingualism }\end{array}$ & $\begin{array}{l}\text { Non-adaptation of borrowed form, } \\
\text { adaptation of meaning of indigenous } \\
\text { terms }\end{array}$ & $\begin{array}{l}\text { Restructuring indigenous color } \\
\text { distinctions, with or without lexical } \\
\text { borrowing }\end{array}$ \\
\hline Substitutive & Now & $\begin{array}{l}\text { Beginning of preference for } \\
\text { Spanish and Spanish } \\
\text { monolingualism }\end{array}$ & Non-adaptation of borrowed forms & $\begin{array}{l}\text { Loss of terms and indigenous } \\
\text { distinctions }\end{array}$ \\
\hline
\end{tabular}

Mayo, speakers from La Misión do not use all available indigenous linguistic resources to the full extent to give names to colors, limiting themselves to a conventionalized vocabulary.

In La Misión, this process of loss of productivity can also be connected to the fact that sometimes speakers just were not able to find the word for the color they were shown. This was the case for $37(4.4 \%)$ answers out of the total of 850 , whereas in Tres de Mayo, there were 932 answers in total, and only three cases where no answer could be produced ( $0.3 \%)$, limited to one consultant. In La Misión, the shift from Yurakaré to Spanish as the dominant language is further advanced, and some speakers are unsure about the range of the Yurakaré terms, so that they are no longer able to give an indigenous name to every color with which they are presented.

In second place, the attrition of indigenous color terminology is reflected by the tendency of some speakers to use Spanish color terms in the color naming test instead of indigenous terms. The Spanish terms are not shared by all speakers, and they do not have the same systematic reference in both communities. They form an index of the difference between the two communities in the degree of knowledge of the Spanish system of color classification, and therefore of the difference in exposure to Spanish. Table 13 presents all Spanish color names used by consultants in the test (types) apart from the ones already discussed above.

The introduction of Spanish terms substituting indigenous ones can be partly explained by the break in intergenerational transmission of specific cultural practices, especially with respect to the color terms linked to the production of traditional dyes, as they appear in color ranges where the indigenous color terms are directly derived from names of tinctorial plants: in the R, YR, Y range with bëymishi, and amaryu, and in the B, PB, P, RP area with itertere, yënêjyënë, and shitiri. In the course of 20th century the Yurakaré stopped wearing their traditional, elaborately painted clothing (called osso), and they abandoned the ritual and ornamental use of body painting (especially face painting). ${ }^{42}$ With the loss of the production and use of the dyes, the color terms connected to them lost their descriptive domain. Consequently, the color terms associated with these dyes are not readily available to younger speakers anymore, and as a result they are insecure of their usage. In the case of the color terms itertere and yënêjyëne, five Spanish loan words are in competition with them, one used in Tres de Mayo, and four in La Misión. Even though these answers were not very frequent (compared to 71 answers itertere, 32 yënêjyëne in La Misión and 50 itertere, 36 yënêjyëne in Tres de Mayo), Table 14 shows the distribution of the loan words byoleta, moraw (both from Spanish, but the first from Cochabamba Spanish, and the second from Beni Spanish), and mayaw (presumably from Quechua and Cochabamba department influence). Note that the competition of these terms is different from the introduction of terms in the B area discussed above (Table 8). Byoleta, moraw and mayaw are replacing indigenous terms, whereas seleste and asul (in combination with shitiri and winuyle) cause a shift in focus of an indigenous term.

Even though replacement is not pervasive yet, and the indigenous system of classification still seems to be quite present in most speakers, the tendency of gradual replacement by other terms is nevertheless in course. In one example of La Misión, a young speaker was not able to interpret the term itertere as a color-denoting term, whereas his mother and father were. As he noted himself, he knew that his parents used the term, but he did not know for what color. His brother had the same reaction, and did not even know the itere plant. Although these examples are singular, they are certainly illustrative of this kind of problem.

Apart from these general trends, the process of loss of the indigenous color system can also lead to peculiar usages. For example, a young woman from la Misión was familiar with the terms itertere and kulákkula, but associated itertere with the stimuli that the majority of consultants classified as kulákkula, while she answered kulákkula symmetrically to stimuli classified as itertere by most consultants. In other words: the classificatory criteria were respected, but the labels itertere and kulakkula were inverted.

\section{Conclusion}

In this paper we have shown that the gradual transformation of the color-classification system of Yurakaré has taken place in three steps. These steps can be termed additive updating, restructuring updating, and substitutive updating. The

\footnotetext{
42 Cf. D’Orbigny (1844) for an illustration of some painted barkcloth shirts. Cf. also Nordenskiöld (2003 [1992]), this latter also includes some illustrations of facial decorations.
} 
three different types of updating can be linked to different phases in the history of contact with the Spanish-speaking community, as well as to linguistic factors and sociolinguistic factors. All factors are summarized in Table 15.

These three phases in the updating process of the Yurakaré color-term system are connected to three points in history where the sociolinguistic situation shows an increasing frequency and intensity of contact with Spanish, resulting eventually in a turnover of the preferred language, which in the most extreme cases (with the youngest generation) results in the loss of active competence in the indigenous language.

This scenario supports Thomason and Kaufman's (1988) conclusion that the outcome of contact situations depends on the sociolinguistic situation. It moreover shows the usefulness of Van Coetsem's (1988) language dominance as a non-fixed notion that can shift (not only within individual speakers, but also in a group of speakers). Socio-historical factors are the catalyzers of contact-induced change, and bilingualism is the medium of change. However, it is the lexical-conceptual structure of a domain that finally conditions the change in terms of possible incorporations or convergences. This goes a step further than Aikhenvald (2007), who only considers linguistic structure as facilitating or hampering the transfer of linguistic material from one language to the other.

Although this is a case study, and we cannot generalize the results, it shows that the evolution of color systems can be strongly influenced by language contact, especially in situations of unequal power relations, and when it concerns languages with significantly different color systems. This is a largely ignored field of study within color theoretic research. It would be illusory to think that we can fully understand the statistical patterns of color-term systems found in the World Color Survey (cf. Kay et al., 1997) without taking into account the inevitable effect of updating processes.

\section{Acknowledgements}

In June 2006 the authors have started a documentation project of the language within the DoBeS (documentation of endangered languages) program. We are thankful to Volkswagen Stiftung, whose funding has made the research reported on in this paper possible. We would also like to thank the speakers of Yurakare that have so generously shared their cultural and linguistic knowledge with us. We are furthermore thankful to Asifa Majid and Stephen Levinson for kindly allowing us the publication of data collected for the project "The language of perception" developed at the Max Planck Institute Nijmegen. Finally, we thank two anonymous reviewers for their valuable comments on an earlier draft of this paper.

\section{References}

Adam, Lucien, 1893. Principes et dictionnaire de la langue Yuracaré ou Yurujure composé le R. P. La Cueva et publié conformément au manuscrit de A. D’Orbigny. Maisonneuve, Paris (Bibliothèque linguistique américaine XVI).

Aikhenvald, Alexandra Y., 2007. Grammars in contact: a cross-linguistic perspective. In: Aikhenvald, A.Y., Dixon, R.M.W. (Eds.), Grammars in Contact: A Cross-Linguistic Typology. Oxford University Press, Oxford, pp. 1-66.

Berlin, Brent, Kay, Paul, 1969. Basic Color Terms: Their Universality and Evolution. University of California Press, Berkeley.

Boria, José, 1897. Relación del Padre J. Boria. El Heraldo, Cochabamba (October 20, 1897).

Coulmas, Florian (Ed.), 1989. Language Adaptation. Cambridge University Press, Cambridge.

De la Fuente, José, n.d. [2000]. Los límites Cochabamba-Beni. Prefectura de Cochabamba, Cochabamba.

De Lucca Dröxler, Manuel F., 2004. Plantas Medicinales del trópico boliviano. Descripción y uso de noventa plantas de la Amazonia boliviana. Praedac, Villa Tunari.

De Viedma, Francisco, 1836. Descripción geográfica y estadística de la Provincia de Santa Cruz de la Sierra. In: de Angelis, Pedro (Ed.), Colección de obras y documentos relativos a la historia antígua y moderna de las Provincias del Río de la Plata, 3. Imprenta del Estado, Buenos Aires, pp. 3-215.

D’Orbigny, Alcide, 1844. Voyage dans l'Amérique méridionale. (Le Brésil, La République orientale de l'Uruguay, la République argentine, la Patagonie, la République du Chili, la République de Bolivia, la République du Pérou), exécuté pendant les années 1826, 1827, 1828, 1829, $1830,1831,1832$ et 1833. Third volume, first part. P. Bertrand/V. Levrault, Paris/Strasbourg.

Hirtzel, Vincent, 2007. L'actualisation du devenir du monde: métamorphose d’un récit mythologique amazonien. In: Rouillard, P., Perlès, C., Grimaud, E. (Eds.), Mobilités, Immobilisme. L'emprunt et son refus. Édition de Boccard, Paris, pp. 185-199.

Girault, Louis, 1984. Kallawaya. Guérisseurs itinérants des Andes: recherches sur les pratiques médicinales et magiques. ORSTOM, Bondy (Mémoires 107).

Gicklhorn, Renée, 1997. Apuntes sobre los Yuracares de Thaddäus Haenke de los años 1796 y 1798 (Translated from German by E. Abastoflor \& J. Ribera). In: Ribera, J. (Ed.), Anotaciones sobre los Yuracaré. Comisión de Pastoral Indígena, Vicariato Apostólico del Beni, Trinidad, pp. 128-136.

Greenberg, Joseph H., 1987. Language in the Americas. Stanford University Press, Stanford.

Hill, Jane, Hill, Kenneth, 1986. Speaking Mexicano: Dynamics of Syncretic Language in Central Mexico. University of Arizona Press, Tucson.

Kay, Paul, Berlin, Brent, Maffi, Luisa, Merrifield, William, 1997. Color naming across languages. In: Hardin, C.L., Maffi, L. (Eds.), Color Categories in Thought and Language. Cambridge University Press, Cambridge, pp. 21-56.

Kroskrity, Paul, 1998. Arizona Tewa Kiva speech as a manifestation of a dominant language ideology. In: Kroskrity, P.V., Schieffelin, B.B., Woolard, K.A. (Eds.), Language Ideologies: Practice and Theory. Oxford University Press, Oxford.

Langacker, Ronald W., 2008. Cognitive Grammar: A Basic Introduction. Oxford University Press, Oxford.

Lenneberg, Eric H., Roberts, John M., 1956. The Language of Experience: A Study in Methodology. Waverly Press, Baltimore.

Lucy, John, 1997. The linguistics of 'color'. In: Hardin, C.L., Maffi, L. (Eds.), Color Categories in Thought and Language. Cambridge University Press, Cambridge, pp. 320-346.

Majid, Asifa, Levinson, Stephen C., 2007. The language of vision I: color. In: Majid, A. (Ed.), Field Manual 10. Informal document Max Planck Institute for Psycholinguistics Nijmegen, Language \& Cognition Group, pp. 22-25.

Mendoza, Simón, Mendoza, Rigoberto, 1893. Exploración de Moleto: informe presentado al Supremo Gobierno de la República por órgano del Señor Prefecto del Departamento de Cochabamba, por la comisión organizada al efecto en el mes de julio último. Imprenta del Heraldo, Cochabamba.

Miller, Leo E., 1918. In the wilds of South America. Six Years of Exploration in Colombia, Venezuela, British Guiana, Peru, Bolivia, Argentina, Paraguay, and Brazil. Charles Scribner's Sons, New York.

Myers-Scotton, Carol, 1993. Duelling Languages: Grammatical Structure in Codeswitching. Clarendon Press, Oxford.

Nordenskiöld, Erland, 2003. Indios y Blancos. En el Nordeste de Bolivia (Translated from German by G. Birk and A.E. García). Plural-APCOB, La Paz (Pueblos de las Tierras Bajas de Bolivia, vol. 18).

New Tribes Mission, 1991. Diccionario Yuracare-Castellano. Misión Nuevas Tribus, Cochabamba 
Ott, André, 1899. Étude sur les couleurs en vieux français. E. Bouillon, Paris.

Pérez, Elizardo, 1962. Warisata. La Escuela-ayllu. Gráfica E. Burillo, La Paz.

Priewasser, Wolfgang, 1916-1920. Alrededor de dos épocas. Apuntes sueltos sobre la historia religiosa del Alto Perú y de la nueva República boliviana, serial publication, Archivo de la comisaría franciscana boliviana, vols. 8-12 (8(85): 51-57; 8(87): 111-115; 8(88): 241-246; 8(89): 260-265; 8(89): 265-269; 8(90): 294-298; 8(90): 298-303; 8(91): 322-325; 8(91): 325-328; 8(92): 351-355; 8(93-94): 389-392; 8(93-94): 393-396; 8(95): 417-423; 8(96): 444-448; 9(97): 4-10; 9(98): 37-47; 9(99): 81-91; 9(100): 109-117; 9(101): 138-146; 9(102): 162-172; 9(103): 205-209; 10(117): 288-291; 10(118): 315-325; 10(119): 358-364; 10(120): 439-447; 11(127): 374-388; 11(128): 403-417; 11(129): 452-460; 11(130): 489-515; 11(131): 537$551 ; 11(132): 587-602 ; 12(136): 113-131 ; 12(137): 174-183 ; 12(139): 178-180 ; 12(140): 335-343)$.

Ribera, Julio, Rivero, Walter, Rocha, Asencio, 1991 (Vocabulario Yuracare-Castellano, Castellano-Yuracare, 3 vols). Equipo Pastoral; MISEREOR, Trinidad.

Roberson, Debi, Davies, Ian R.L., Davidoff, Jules, 2000. Color categories are not universal: replications and new evidence from a stone-age culture. Journal of Experimental Psychology 129, 369-389.

Roberson, Debi, Davidoff, Jules, Davies, Ian R.L., Shapiro, Laura R., 2005. Color categories: Evidence for the cultural relativity hypothesis. Cognitive Psychology 50, 378-411.

Rodríguez, Benito, 1789. [Testimonio da do en la información pedida por el cura Angel Mariano Moscoso sobre el estado del camino a la nueva reducción de la Asunción de los Yurakaré, Cochabamba, 1st of July 1789] ff. 117v-119v. Biblioteca y Archivo Nacional de Bolivia, Moxos T.IX. Paleographic transcription Mauricio Valcanover.

Rodríguez Ostria, Gustavo, 1997. Historia del Trópico Cochabambino 1768-1972. Prefectura de Cochabamba, Cochabamba.

Rosch, Eleanor, 1973. Natural categories. Cognitive Psychology 4, 328-350.

Rosch Heider, Eleanor, 1972. Probabilities, sampling, and ethnographic method: the case of Dani color names. Man 7, $448-466$.

Sanez Mamani, Jesús, 1992. Evaluación Agronómica del Palillo “Curcuma longa” en los Yungas de La Paz. Universidad San Andrés, La Paz.

Silverstein, Michael, 1979. Language structure and linguistic ideology. In: Clyne, P.R., Hanks, W.F., Hofbauer, C.L. (Eds.), The Elements: A Parasession on Linguistic Units and Levels. Chicago Linguistic Society, Chicago, pp. 193-247.

Saunders, Barbara A.C., van Brakel, Jaap, 1997. Are there non-trivial constraints on colour categorization? Behavioral and Brain Science 20 (2), 167-228.

Suárez, Jorge A., 1974. Macro-Pano-Tacanan. International Journal of American linguistics 37 (3), $137-154$.

Swadesh, Morris, 1962. Afinidades de las lenguas amerindias. In: Baldus, H. (Ed.), Akten de 34. Amerikanistenkongresses. Fred begrer, Horn-Wien, pp. $729-738$.

Tornay, Serge, 1978. Introduction. In: Tornay, S. (Ed.), Voir et nommer les couleurs. Laboratoire d'Ethnologie et de Sociologie Comparative, Nanterre (pp. ix-li).

Thomas, Evert, Vandenbrook, Ina, 2006. Guía de plantas medicinales de los Yuracarés y Trinitarios del Territorio Indígena y Parque Nacional Isiboro-Sécure, Bolivia. Imprenta Sirena, Santa Cruz de la Sierra.

Thomason, Sarah G., Kaufman, Terrence, 1988. Language Contact, Creolization, and Genetic Linguistics. University of California Press, Berkeley.

Van Coetsem, Frans, 1988. Loan Phonology and the Two Transfer Types in Language Contact. Foris Publications, Dordrecht.

Van Coetsem, Frans, 1995. Outlining a model of the transmission phenomenon in language contact. Leuvense Bijdragen $84,63-85$.

Van Coetsem, Frans, 2000. A General and Unified Theory of the Transmission Process in Language. Winter, Heidelberg.

Van Gijn, Rik, 2006. A Grammar of Yurakaré. Ph.D. Thesis, Radboud University Nijmegen.

Weddell, Hugues Algernon, 1853. Voyage dans le nord de la Bolivia et dans les parties voisines du Pérou ou visite au district aurifère de Tipuani. P. Bertrand/ H. Baillère, Paris/London.

Woolard, Kathryn, Schieffelin, Bambi, 1994. Language ideology. Annual Reviews in Anthropology 23, 55-82.

Rik van Gijn wrote his PhD on the grammar of Yurakaré, and he is, apart from his documentation work, currently carrying out a cross-linguistic research on subordination strategies in the languages of South America at the Radboud University Nijmegen. Research interests: South-American languages, subordination, language typology, language contact and change.

Vincent Hirtzel is an associated researcher of the Laboratoire d'Anthropologie Sociale, where he wrote his PhD thesis on the conception of the self in Yurakaré sociality and culture. Research interests: general anthropology, linguistic anthropology and Amazonian ethnohistory.

Sonja Gipper is currently writing her PhD thesis on the interactional use of evidential markers in Yurakaré at the Max Planck Institute Nijmegen. Research interests: evidentiality, cross-linguistic pragmatics and interactional linguistics. 